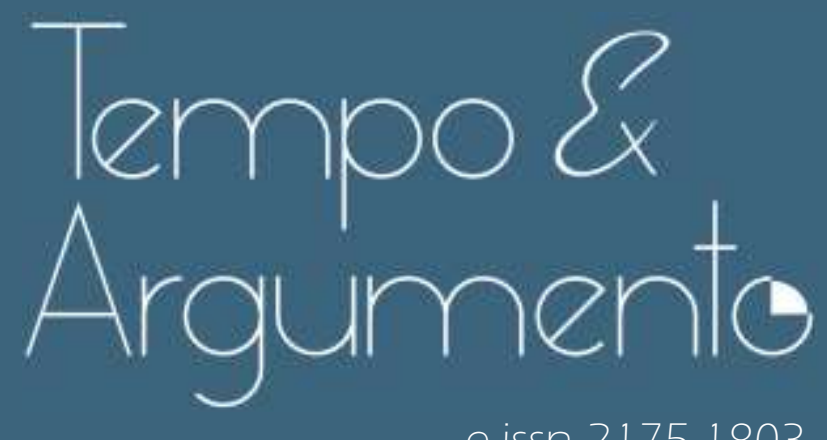

e-issn 2175-1803

\title{
Viriato da Cruz: da luta anticolonial ao exílio em Pequim
}

- Angela Lazagna

Doutora em Ciência Política pela Universidade Estadual de Campinas (UNICAMP).

Estágio Pós-Doutoral em História da África na Universidade Federal Fluminense (UFF).

Curitiba, PR - BRASIL

lattes.cnpq.br/8698618932999986

alazagna@gmail.com

(D) orcid.org/0000-0002-7350-2461

Para citar este artigo:

LAZAGNA, Angela. Viriato da Cruz: da luta anticolonial ao exílio em Pequim.

Tempo e Argumento, Florianópolis, v. 13, n. 34, e0107, set./dez. 2021.

do http://dx.doi.org/10.5965/2175180313342021 e0 107

Recebido: 21/06/2021

Aprovado: 17/08/2021 


\title{
Viriato da Cruz: da luta anticolonial ao exílio em Pequim*
}

\begin{abstract}
Resumo
O objetivo principal deste artigo é analisar a trajetória política de Viriato Francisco Clemente da Cruz (1928-1973), no contexto dos movimentos das independências africanas, mais especificamente, de Angola. Como fundador do Movimento Popular de Libertação de Angola (MPLA), sua trajetória transita entre as afinidades e tensões com os movimentos independentistas africanos no exílio. Para além dos cenários locais, regionais e globais nos quais esses movimentos se fusionavam e fissionavam, e para além dos rótulos e das categorias de acusação/celebração atribuídas a Viriato da Cruz e à luz de disputas muito específicas, serão considerados, através de pesquisas em arquivos e entrevistas, aspectos pouco conhecidos da sua vida política.
\end{abstract}

Palavras-chave: nacionalismo; anticolonialismo; Angola; trajetórias políticas.

\section{Viriato da Cruz: from the anti-colonial struggle to exile in Beijing}

\begin{abstract}
The main objective of this paper is to analyze the political path pursued by Viriato Francisco Clemente da Cruz (1928-1973) in the context of the African independence movements, more specifically Angola. As the founder of the Movimento Popular de Libertação de Angola (MPLA), he treaded a path of affinities and tensions with the African independence movements while in the diaspora. Beside the local, regional and global scenarios in which those movements merge and fission each other, and in addition to any labels or accusatory/celebratory designations assigned to Viriato da Cruz, and under the light of very specific disputes, we will seek to shed light on little-known aspects of his political life.
\end{abstract}

Keywords: nationalism; anticolonialism; Angola; political trajectories.

\footnotetext{
* Agradeço a Marcelo Bittencourt pelo constante apoio e supervisão desta pesquisa; ao Prof. Michel Cahen por viabilizar o meu contato com o Sr. José Carlos Horta, quando da minha estadia em Lisboa (nov./2018 - jul./2019) e pela autorização para que eu pudesse consultar os arquivos - inéditos - da socióloga e estudiosa de Angola, Christine Messiant, que se encontram, ainda, em estágio de classificação e digitalização, na Fundação Mário Soares (FMS); ao Sr. Ayres de Menezes, por sua disponibilidade em me conceder importantes informações e documentos concernentes ao percurso político de Hugo Azancot de Menezes; à Sra. Maria de La Salete Guerra de Menezes, pela disponibilidade para conversar através do WhatsApp; a Nelson Pestana, pela atenta leitura da versão preliminar deste artigo, bem como pelas suas valiosas informações e sugestões; ao CNPq (Conselho Nacional de Desenvolvimento Científico e Tecnológico) pela bolsa de estudos e auxílio financeiro (Bolsas no País - Pós-Doutorado Júnior - PDJ - № Proc.: 156044/2018-8) que possibilitaram a realização desta pesquisa. As informações e conclusões presentes neste texto são de minha inteira responsabilidade.
} 


\section{Introdução}

Ainda hoje, nos manuais escolares da Angola pós-independência, o aspecto mais salientado da figura de Viriato da Cruz é o de poeta. Tal como o retrata Francisco Soares, da Cruz pode ser considerado como "...o grande paradigma da literatura nacionalista angolana e o seu máximo expoente poético" (2008, p. 71). No entanto, apenas em novembro de 2018 a importância do Viriato poeta foi reconhecida oficialmente pelo Estado angolano, ao ser postumamente distinguido com o Prémio Nacional de Cultura e Artes. Segundo uma matéria publicada no jornal angolano Nova Gazeta, essa premiação ocorreu "...nove anos depois de uma 'ordem superior' the ter 'roubado' o galardão". E continua: "Entre académicos, há quem fale em 'reposição da justiça', enquanto outros elogiam o político 'convicto' que 'renunciou a vida pessoal para se dedicar à Angola'" (SANTIAGO, 2018, p. 1).

Logo, a primeira questão que podemos lançar acerca do percurso político do nacionalista, marxista e revolucionário angolano Viriato da Cruz é a seguinte: será que esta dimensão - quase inofensiva - do seu legado retrata de maneira fidedigna uma trajetória que é, na verdade, plural, multívoca, multissituada e, necessariamente, não-linear? Como idealizador e fundador do Partido Comunista de Angola (PCA) e do Movimento Popular de Libertação de Angola (MPLA), a trajetória de Viriato transita entre afinidades e tensões com os movimentos independentistas africanos no exílio e, posteriormente, define-se com a sua aproximação, também não isenta de conflitos, do chamado "socialismo chinês".

Por que retornar à figura de Viriato da Cruz? Através das pesquisas realizadas até agora - e da revisão da literatura correspondente - a trajetória multifacetada de Viriato da Cruz se apresenta como um caso paradigmático para indagar - do ponto de vista empírico e teórico - as tensões entre nacionalismo e construção do Estado em contextos anticoloniais, bem como as dinâmicas de circulação das ideias entre os intelectuais africanos a partir da década de 1950. Trata-se de uma trajetória cosmopolita e transnacional, cujos horizontes de referências incluem interlocuções com intelectuais e políticos oriundos de países tão diversos como Brasil, França, Portugal, Argélia, Alemanha, Congo, Guiné, Bélgica e China. 
Mesmo se tratando "[...] de uma figura de primeiro plano do nacionalismo angolano depois de 1945", o Viriato político, nacionalista e marxista ainda hoje se encontra eclipsado em seu país (LABAN; MESSIANT, 2003, p. 27). É preciso lembrar que na história e nas publicações oficiais do MPLA, a figura de Agostinho Neto ${ }^{1}$ aparece como o primeiro presidente do MPLA e José Eduardo dos Santos, como o segundo. Não encontramos nenhuma referência ou reconhecimento a Viriato da Cruz como o seu ideólogo, principal fundador e secretário geral (HISTÓRIA DO MPLA, 2014).

Apesar da existência de importantes investigações que comprovam a fundação do MPLA em 1960, em Túnis, ou seja, no exterior (BITTENCOURT, 1997, 2002; MABEKO-TALI, 2018; MESSIANT, 2008b; PACHECO, 1997), a versão ainda e mil vezes - propagada é de que "Em 10 de dezembro de 1956, um grupo de patriotas angolanos deu a conhecer o Manifesto do Amplo Movimento de Libertação de Angola (MPLA) [...]. Esta é a data oficial da sua fundação” 2. Afirmase, ademais, que o movimento teria surgido da fusão dos já existentes “...PLUAA - Partido de Luta Unida dos Africanos de Angola, o MIA (Movimento para a Independência de Angola), o MINA (Movimento pela Independência Nacional de Angola e o PCA (embrião do efémero Partido Comunista de Angola)...”.

Christine Messiant, em seu artigo sugestivamente intitulado "Chez nous, même le passé est imprévisible" ("Em Angola, até o passado é imprevisível”), ressalta - quanto ao primeiro período do MPLA, ou seja, anterior à independência - que a redação da sua história toma um caminho "clássico" e "banal" de distorção, mitologização e instrumentalização que culminará na história oficial (à exemplo de muitas outras histórias oficiais) do nacionalismo angolano. História esta que se constrói 1. Contra as outras duas organizações nacionalistas -

\footnotetext{
Agostinho Neto (1922-1979) nasceu em Ícolo e Bengo, em uma família negra de classe média. Graças a uma bolsa de estudos da Igreja Protestante em Angola, pôde estudar medicina em Coimbra, Portugal, onde chegou em 1947. Enquanto estudante, militou no Movimento de Unidade Democrática (MUD-Juvenil). Entre 1952 e 1958, foi preso várias vezes por "subversão". Em 1958, conclui o seu curso de medicina, regressando a Angola em 1959.

${ }^{2}$ Cf. MPLA. HISTÓRIA. Disponível em: http://m.mpla.ao/mpla/historia. Acesso em: 30 de nov. 2020. Idem, ibdem. Essa versão é também veiculada pelo documentário sobre a luta de libertação nacional de Angola - Independência - produzido em Angola pela Associação Tchiweka de Documentação (ATD), que alberga o acervo pessoal de Lúcio e Ruth Lara, e pela produtora Geração 80. O documentário foi lançado em 2015, ano do quadragésimo aniversário da independência de Angola (trailer disponível em: https://youtu.be/JDS-n6e56fw. Acesso em: 30 nov. 2020).
} 
UPA/FNLA (União das Populações de Angola/Frente Nacional de Libertação de Angola) e UNITA (União Nacional para a Independência Total de Angola) - através de um processo de supressão do papel desses movimentos na história e de estigmatização desses movimentos; 2. Como uma história purificada dos seus aspectos menos aceitáveis (como os assassinatos de Matias Miguéis e José Miguel, por exemplo), depurada das suas crises e contradições; 3. Contra os seus dissidentes, denominados fracionistas e, no limite, eliminados da história (MESSIANT, 2008b, p. 158-159).

O presente artigo tem como objetivo, através da experiência concreta proporcionada pelos itinerários de Viriato da Cruz, trazer alguns elementos para descontruir esta e outras narrativas oficiais. Quem era, afinal, Viriato da Cruz? Por que o seu legado interpela, ainda hoje, as certezas das historiografias nacionalistas consagradas? De que maneira a sua trajetória pode ajudar a repensar as dinâmicas de composição e recomposição dos movimentos de libertação das ex-colônias portuguesas - mais especificamente, de Angola? Até que ponto é possível analisar a sua trajetória sob a simples dicotomia do cisma sino-soviético? A atribuição de um "maoísmo ideológico" a Viriato da Cruz tem funcionado como um apelativo ora acusatório (de parte de seus detratores), ora celebratório (de parte de seus defensores). No entanto, como testemunha ocular da experiência da Revolução Cultural Chinesa e crítico do revisionismo soviético ${ }^{5}$, Viriato logrou, a partir do "não lugar" que paradoxalmente the foi imposto na China, onde faleceu em 1973 (e apesar das condições adversas nas quais se encontrava no fim de sua vida), apontar alguns dos limites e contradições que perpassaram esse período de "construção do socialismo chinês".

\footnotetext{
${ }^{4}$ A UPA, fundada em 1958, era um movimento com uma forte base no grupo etnolinguístico bakongo, presente em ambos os lados da fronteira entre Angola e o Congo-Léopoldville. Encontrava-se, pois, mais enraizada no norte de Angola. Seus líderes, entre eles Holden Roberto, possuíam uma estreita relação com o Congo-belga, para onde vários angolanos migraram em busca de melhores condições de vida. Ver, nesse sentido, Bittencourt (2002, cap. III, v. 1).

5 Em uma carta de Viriato da Cruz, escrita em Pequim, ao seu grande amigo José Carlos Horta, datada de 14 de outubro de 1970, Viriato expõe abertamente suas críticas às concepções marxista-leninistas, ou seja, estalinistas, que sustentavam a existência de "países socialistas"; dito de outro modo, que defendiam a tese do SOREX (Socialismo Realmente Existente). Esta carta se encontra publicada em na obra organizada por Michel Laban e Christine Messiant. Ver, neste sentido, Cruz, 2003a.
} 
Os trabalhos sobre estudos de trajetórias de lideranças independentistas africanas são vastos e numerosos. A perspectiva metodológica que privilegiamos aqui busca superar as vertentes biográficas pautadas em um "individualismo metodológico". Para tanto, somos sensíveis às advertências formuladas por Pierre Bourdieu (1986) em seu conhecido ensaio sobre a "ilusão biográfica", em que ressalta que “...não é possível compreender uma trajetória [...] sem que tenhamos previamente construído os estados sucessivos do campo no qual ela se desenrolou e, logo, o conjunto das relações objetivas que uniram o agente considerado [...] ao conjunto dos outros agentes envolvidos no mesmo campo e confrontados com o mesmo espaço dos possíveis” (BOURDIEU, 1986, p. 72). Logo, para além do "método biográfico" - seja veiculado pelos detratores, seja pelos defensores - o que visamos é evidenciar o caráter "construído" das historiografias nacionais, ou melhor, indagar sobre essas historiografias a partir, por assim dizer, dos "seus Outros". E, neste caso, mais especificamente, através do resgate de outras vozes. Para dizê-lo nas palavras de Michel Laban e Christine Messiant (2003, p. 27), do resgate das "[...] histórias dos que foram expulsos ou deixados pelo caminho, daqueles que se afastaram [...]".

\section{Breve biografia: Viriato da Cruz em Luanda}

Viriato Francisco Clemente da Cruz nasceu em Kikuvo, Porto Amboim, Angola, em 28 de março de 1928. Segundo Edmundo Rocha ${ }^{6}$ (2008, p. 111), era filho de pai e mãe mestiços: Abel Francisco da Cruz e Clementina Clemente da Cruz. Era o mais velho dos quatro filhos do casal e possuía três irmãs: Bebiana, Celestina e Gilberta. Ao se separar do marido após seis anos de vida em comum, Clementina e seus filhos vão viver em Luanda, com a avó materna de Viriato. 0 pai, proprietário de fazendas de algodão e cabeças de gado e, portanto, abastado, nunca contribuiu para a formação escolar dos quatro filhos. Tampouco apoiou

\footnotetext{
${ }^{6}$ Edmundo Vicente de Melo Rocha (1931-2020) nasceu em Porto Amboim, Angola, onde realizou o ensino primário e parte do ensino secundário, concluindo-o em Coimbra, Portugal, em 1951. Iniciou o curso superior em Medicina em Paris, concluindo-o em Lisboa. Especializou-se em pediatria e em imunoalergologia, realizando um doutorado em pediatria na Faculdade de Medicina de Argel (Argélia). Foi membro do CVAAR (Corpo Voluntário de Ajuda aos Angolanos Refugiados) no Congo-Léopoldville. Refugiou-se na Argélia até a independência de Angola, em 1974. Foi militante do nacionalismo angolano desde os primórdios.
} 
os estudos superiores de Viriato - que só poderiam ser realizados fora de Angola -, a despeito deste manifestar seu desejo de cursar o ensino superior. Em uma carta endereçada ao pai, de 4 de novembro de 1946, Viriato manifesta o seu desejo em cursar arquitetura:

Outro assunto que preciso tratar com o Pai. Faltam apenas uns 50 e tantos dias para eu fazer o exame do sexto ano, convém, portanto, saber desde já se o pai está disposto a mandar-me, para o ano, tirar um curso na Metrópole. Eu desejo, porque é do meu gosto, cursar para Arquitectura. Este curso é de 5 anos a 6. Agradecia que o pai tomasse uma resolução firme e me mandasse a resposta o mais cedo possível ${ }^{7}$ (CRUZ, 1946, p. 1, grifo do autor).

Viriato recebe sua educação em Luanda, ingressando primeiramente no Colégio D. João II, onde cursou os três anos liceais e, posteriormente, no Liceu Nacional de Salvador Correia (ROCHA, 2008, p. 112) ${ }^{8}$. Em 1948, quando já estudava no Liceu Salvador Correa, é acometido por uma tuberculose e internado no Hospital Maria Pia, interrompendo seus estudos por cerca de seis meses. Mario de Andrade, em uma entrevista a Michel Laban, relata que estreitara suas relações com Viriato entre 1947-48, e que o visitara, às vésperas de sua partida a Lisboa (outubro de 1948), no hospital Maria Pia, onde se encontrava internado em virtude de problemas pulmonares (ANDRADE, 2008, p. 50-53). Mário António Oliveira9 $^{9}$ (1990, p. 373), cujo relato sobre a data da internação de Viriato coincide com a versão de Mário de Andrade, diz que foi "No isolamento ditado pela doença [que] Viriato da Cruz escrevera todos os exemplares poemas que se conhecem [...]" (1990, p. 374)10. Segundo Nelson Pestana (2021, p. 1), é por essa altura que

\footnotetext{
Agradeço a Nelson Pestana por ter compartilhado comigo uma cópia desta carta, que the foi cedida pela sobrinha de Viriato, Regina Maria da Cruz Queiroz, que vive em Portugal. Infelizmente, apenas a primeira página desta carta está disponível.

3 Segundo Emundo Rocha, estas informações the foram fornecidas por uma das irmãs de Viriato, Celestina Cruz.

${ }^{9}$ Mario António Fernandes de Oliveira (1934-1989) nasceu em Maquela do Zombo (Uíge), Angola. Viveu em Luanda desde a infância, onde cursou seus estudos primários e secundários. Militante nacionalista e de esquerda, foi um dos fundadores do Partido Comunista de Angola (PCA) e do PLUAA. Amigo de Viriato da Cruz, acompanhou o seu percurso até a sua saída de Luanda, em 1957. Em 1963, vai para Portugal, onde se licencia em Ciências Sociais e Política Ultramarina. Doutorou-se em 1987 em Estudos Portugueses (Literatura Africanas de Expressão Portuguesa). Atuou como professor auxiliar da Faculdade de Ciências Sociais e Humanas da Universidade Livre de Lisboa, foi diretor do Serviço para a Cooperação com os Novos Estado Africanos, da Fundação Calouste Gulbenkian, e presidente da Seção de Literatura da Sociedade de Geografia de Lisboa, cidade onde viveu até o seu falecimento.

${ }^{10}$ Ainda segundo Mário António (1990, p. 374), Viriato escreveria mais tarde, em Lubango (para onde havia sido transferido, da secretaria da Escola Industrial, em Luanda, para a do Liceu Diogo Cão), o poema "Sá de Bandeira" (nome colonial da cidade).
} 
Viriato publica o seu primeiro texto de Arte, publicado no jornal O Farolim. Em entrevista a Christine Messiant (2003, p. 235, nota 48), Mário de Alcântara Monteiro, que militou com Viriato em iniciativas culturais, disse que ele esteve, por volta de 1947, dois meses internado, período em que traduziu grandes passagens de O Capital, de Karl Marx, que eram entregues, manuscritas, aos seus companheiros ${ }^{11}$. Mário António F. Oliveira (1990, p. 373), além de sublinhar o valor poético e literário de Viriato da Cruz, ressalta o seu talento como caricaturista. Segundo o seu relato: "Os estudantes mais velhos que me impressionaram no ano em que entrei para o liceu de Luanda, foram Antero de Abreu, por um seu desempenho teatral, Viriato da Cruz, pelo talento de caricaturista e Mário de Alcântara Monteiro”. Sublinha, ademais, que “[...] entre 1948 e 1952, surgiu e logrou sua primeira expressão o movimento literário que representou o primeiro assomo de uma consciência nacional em Angola, em relação ao qual como até agora, o lugar primeiro foi entregue a Viriato da Cruz [...]".

Edmundo Rocha (2008, p. 118) ressalta que, nessa altura, existiam em Luanda alguns portugueses antifascistas, progressistas ou mesmo comunistas, que se encontravam exilados em Angola por questões políticas. "Alguns deles", diz, "eram professores do Liceu Salvador Correia, como o Dr. Amado Alves e sua mulher Isabel. Estes anti-salazaristas serviam de fermento à formação marxista de alguns jovens angolanos, em especial de António Jacinto ${ }^{12}$, de Mário António, de Viriato da Cruz e de Tomáz Jorge [...]”.

Já Juliana Santil (2006) chama a atenção para a importância do intercâmbio cultural e político entre os jovens nacionalistas angolanos e um grupo de jovens escritores brasileiros de Florianópolis (Santa Catarina) que

\footnotetext{
${ }^{11}$ Ao que parece, Edmundo Rocha (2003, p. 113) se equivocou com as datas ao afirmar que Viriato teria interrompido o Liceu no 70 ano, em 1945, aos 17 anos, em virtude de uma tuberculose. Também Mário de Alcântara Monteiro se equivocou quanto ao ano concernente à internação de Viriato.

12 António Jacinto do Amaral Martins (1924-1991) nasceu em Luanda, Angola. Realizou seus estudos em Golungo Alto e em Luanda (Liceu Salvador Correia). Foi um dos fundadores do PCA e do PLUAA. Foi preso em 1959 ("Processo dos 50"). Foi preso novamente em 1961, sendo deportado, em 1963, ao campo de concentração do Tarrafal (Cabo Verde). Foi solto em 1972, após uma intensa campanha internacional, sendo obrigado a fixar residência em Lisboa. Fugiu para Argel (Argélia) em 1973 e aderiu à guerrilha do MPLA. Foi diretor do CIR (Centro de Instrução Revolucionária), Kalunga, na 2a Região Político-Militar e do CIR Binheco, no Mayombe. Integrou a primeira delegação do MPLA que chegou a Luanda em 8 de novembro de 1974. Após a independência, foi Ministro da Educação e Cultura, Secretário de Estado da Cultura e participou da Direção do MPLA.
} 
formavam o grupo Sul, durante os anos de 195013. Este intercâmbio se constituiu em uma importante fonte através da qual António Jacinto e Viriato da Cruz obtinham, além de revistas e romances, literatura marxista, sem qualquer mediação do Partido Comunista Português (PCP) ou do Partido Comunista Brasileiro (PCB) - e apesar da ligação entre Jacinto e o PCB ${ }^{14}$. Nas cartas enviadas por Viriato da Cruz e António Jacinto ao escritor Salim Miguel (2005), editor da revista sul, aparecem títulos de livros concernentes a autores marxistas soviéticos e chineses que eram encomendados por ambos. Mais tarde, o próprio Viriato da Cruz reconheceria, tal como ressalta Santil (2005, p. 142), a importância desse intercâmbio para a sua formação crítica, bem como a dos seus companheiros de luta:

No entanto, os contatos entre jovens angolanos e jovens escritores brasileiros conduziram à introdução clandestina em Angola de livros e revistas que engajaram uma parte da juventude no debate sobre os principais problemas do pós-guerra: a questão social, o fascismo e a democracia, o colonialismo, a autodeterminação dos povos, etc (CRUZ, 1964, p. 9-10)

Entre 1948 e 1953, Viriato participou dos círculos políticos e literários de Luanda, integrando a Associação dos Naturais de Angola (ANANGOLA) onde, ao lado de António Jacinto, Leston Martins, Humberto da Silvan e Mário Alcântara Monteiro, dirigiu o setor cultural (ROCHA, 2003, p. 75). Em 1950, fundou, com António Jacinto, o Movimento dos Novos Intelectuais de Angola (MNIA), cujo

\footnotetext{
${ }^{13}$ O objetivo do grupo Sul, no qual se destacavam Salim Miguel, Eglê Malheiros, Walmor Cardoso da Silva, Aníbal Nunes Pereira, Ody Fraga, era divulgar os princípios do modernismo, a fim de romper com o conservadorismo que caracterizava o meio cultural de Florianópolis. Para tanto, o grupo organizava uma série de atividades culturais no domínio do teatro, do cinema, das artes plásticas e da literatura. Este domínio em particular foi marcado pela publicação, em 1948, da revista Sul, que acaba se convertendo em "[...] um veículo de propagação da literatura de Angola, de Moçambique e de São Tomé e Príncipe e que publica, de 1952 a 1957, uma imensa série de textos (enviados da África a Florianópolis e conferindo a esses intelectuais uma tribuna de expressão inédita)" (SANTIL, 2006, p. 395).

14 Ainda segundo Santil (2006), António Jacinto foi, do grupo dos jovens angolanos, quem primeiramente se relacionou com os escritores do grupo Sul. Mas isto não se deu em virtude da sua ligação com o PCB. A origem da ligação dos jovens escritores brasileiros com a África data de 1948 e foi mediada pelo escritor, oriundo do Rio de Janeiro, Marques Rebelo, que incentivou os jovens escritores da Sul a estabelecerem contatos com outros grupos culturais de Portugal e Moçambique. Augusto dos Santos Abranches, escritor e desenhador português que vivia em Nampula, Moçambique, foi o primeiro a ser contatado por Salim Miguel. Abranches the enviou textos originais de escritores moçambicanos e angolanos. Sendo o receptor de exemplares da revista Sul, ele os reenviou a Maputo (ex-Lourenço Marques), Moçambique e Luanda (Angola), bem como enviou a Salim Miguel o endereço de António Jacinto.
} 
leitmotiv, "Vamos descobrir Angola", já havia sido lançado em 1948¹5. Destacamse no MNIA, além de Viriato da Cruz e António Jacinto, Mário Alcântara Monteiro, Bandeira Duarte, Leston Martins, Maurício Gomes, Humberto Silva, Lília da Fonseca, Mário António de Oliveira, Tomás Jorge Vieira da Cruz, Monteiro Silvan, entre outros (ROCHA, 2003, p. 72).

O movimento possuía um caráter de contestação, expresso pelos poemas, contos e artigos publicados na revista Mensagem - a voz dos naturais de Angola (1951 e 1952), cujo objetivo era a construção da "Nova Cultura Angolana" através da revelação da "angolanidade subjacente" (RAMOS, 2017, p. 278). Apesar da sua curta duração, já que a revista foi rapidamente encerrada por força da censura do Estado Novo - foram publicados quatro números, os três últimos em um só caderno -, Mensagem "[...] marcou o início da literatura angolana de protesto e de consciencialização" (ROCHA, 2003, p. 75). Os animadores do MNIA propunham descrever as duras condições sociais nos musseques ${ }^{16}$ e expor reivindicações nacionalistas. O objetivo desse movimento era a criação de uma literatura propriamente angolana, quebrando as imposições colonialistas de Portugal ${ }^{17}$. Mas, segundo Edmundo Rocha, Viriato e Mário António passariam a discordar da política, considerada reformista, da ANANGOLA, abandonando-a. Ambos participam das atividades na Liga Nacional Africana, onde, junto aos seus amigos Ilídio Machado, Matias Miguéis ${ }^{18}$ e André Franco, Viriato desenvolveu atividades

\footnotetext{
${ }^{15}$ Sobre a polêmica em torno do slogan "Vamos descobrir Angola", consultar o artigo de Mário António F. Oliveira (1990, p. 371-383), "Memória de Luanda (1949-1953): 'vamos descobrir Angola", em que afirma que este slogan não se materializou. Por sua vez, Mário de Andrade (2008, p. 5961) fornece mais detalhes acerca desta questão, argumentando sobre a legitimidade do seu emprego.

${ }^{16}$ Musseque: bairro, geralmente de construções precárias, nos arredores de uma cidade, onde habitam os moradores menos favorecidos economicamente.

17 Um ofício da delegação da PIDE (Polícia Internacional e de Defesa do Estado), em Luanda, à Direção de Lisboa classifica-o como um movimento de "tendências separatistas" (PIDE, 1957, apud SILVEIRA, 2003, p. 5).

${ }^{18}$ Matias Miguéis (1917-1965) nasceu em Novo Redondo (atual Sumbe), Angola. Era amigo de Viriato da Cruz e Ilídio Machado. Trabalhava como contabilista na MAMPEZA, empresa que o transfere para Ponta Negra, onde mantém intercâmbio epistolar com companheiros de Luanda e com brasileiros ligados à revista O Cruzeiro (que circulava em Angola), como David Nasser e a escritora Raquel de Queiroz. Foi um dos fundadores do MPLA e chegou a ser o seu vicepresidente quando Agostinho Neto assumiu a presidência. De acordo com Rocha (2008, p. 175), adepto à ala do MPLA liderada por Viriato da Cruz, foi assassinado, com José Miguel Francisco, por um destacamento do MPLA, nas matas de Dolisie (atual Loubomo, República do Congo) no regresso de uma conferência ocorrida em Jacarta (Indonésia) e após um julgamento sumário, em que foi acusado de alta traição.
} 
sociais e se dedicou, ademais, à militância política clandestina (ROCHA, 2003, 2008).

\section{A fundação do Partido Comunista Angolano}

Em 12 de novembro de 1955, é assinada a ata de fundação do Partido Comunista Angolano por Viriato da Cruz, Ilídio Machado, António Jacinto e Mário António Fernandes de Oliveira, que adotaram os respectivos pseudônimos: Mon'a Mundu19, Paulo Costa, Carlos Duarte e José Nunes (ROCHA, 2003, p. 100)20. Segundo interrogatórios da PIDE (Polícia Internacional e de Defesa do Estado) que o historiador Carlos Pacheco consultou (1997, p. 26, nota 4), a elaboração dos estatutos dessa organização foi de autoria do próprio Viriato, que teria se baseado nos estatutos do PCB. Em seu depoimento, Mário António F. de Oliveira revela "Que criado o Partido Comunista de Angola, o Viriato da Cruz encarregou-se de the dar os seus estatutos e estes provieram da adaptação dos estatutos do Partido Comunista Brasileiro, publicados numa revista do Brasil, adaptação com que todos concordaram e cujas cópias obtiveram" (OLIVEIRA, 1959 apud PACHECO, 1997, nota 4, p. 64-65, grifo do autor).

Entretanto, importa aqui considerarmos a advertência crítica de Christine Messiant (2008b, p. 192) sobre a interpretação dos documentos presentes nos arquivos da PIDE: "[...]estes arquivos não constituem em absoluto uma fonte que possa ser considerada, sem reservas, como 'a verdade' - nem, obviamente, toda a verdade, nem mesmo, talvez, uma verdade". E constata "[...] que este problema básico não fora, nem discutido, nem tampouco colocado no livro de Carlos Pacheco [MPLA - um nascimento polémico (falsificações da história)" (MESSIANT, 2008b, p. 192). Partindo desta advertência, é possível supor que aqueles que foram presos, e que muitas vezes estiveram sob tortura, tenham muitas vezes transferido as responsabilidades e as autorias para aqueles que não mais corriam o risco de serem apanhados pela PIDE. É o que deduz Viriato da

\footnotetext{
${ }^{19}$ Mon'a Mundu, do kimbundu, significa "Filho do Mundo".

20 Uma cópia da Acta de Fundação do Partido Comunista de Angola pode ser consultada em Rocha (2008, p. 370-371).
} 
Cruz a respeito dessas prisões, em uma carta a Lúcio Lara ${ }^{21}$, datada de 06 de dezembro de 1959: "De certeza, os nossos compatriotas, num acto inteligente, lançaram sobre a malta que está no estrangeiro, algumas acusações portuguesas. [...] Em nenhuma parte do mundo civilizado se reconhece o direito de extradição por 'crimes' políticos” (CRUZ, 2017c, p. 214-215). Nesse sentido, é provável que a participação de António Jacinto na elaboração dos Estatutos do PCA tenha sido tão importante quanto a de Viriato da Cruz.

Mas, como nos chama a atenção Nelson Pestana (2016, p. 138), os estatutos do PCA não são uma mera cópia dos estatutos do PCB. Pestana sublinha que, a despeito do objetivo estratégico comum a ambos os Estatutos - a instauração de um "regime democrático popular" -, existia uma importante diferença entre eles quanto às "tarefas principais" do partido, em virtude da "diferença de contextos". Enquanto no estatuto do PCB, o objetivo é a realização da "[...] unidade das 'forças anti-imperialistas e anti-feudais' para 'derrubar o poder dos latifundiários e grandes capitalistas' e 'libertar o Brasil do jugo imperialista'” (PCB, 1954 apud PESTANA, 2016, p. 139), o PCA, nascido num "contexto colonial", almejava

[...] "conquistar a completa independência nacional" através do "despertar e elevar [d]a consciência dos interesses particulares de todas as forças e correntes anti-imperialistas da sociedade angolana [procurando] organizá-las, movimentá-las e aliá-las na sua luta contra o inimigo comum - o imperialismo - e dar-lhes unidade de acção." (PCA, 1954 apud PESTANA, 2016, p. 139)

Segundo Messiant, Viriato da Cruz, enquanto nacionalista africano, tampouco se identificava com a linha do PCP, pois considerava que "[...] os comunistas portugueses estavam 'entalados' entre um 'lusotropicalismo' não declarado [...] e um paternalismo característico dos comunistas dos países

\footnotetext{
${ }^{21}$ Lúcio Lara (1928-2016) nasceu em Nova Lisboa (Huambo) de pai português (instalado em Angola no início do século XX) e de mãe neta de mestiça de um soba (chefe tradicional) de Libolo. Realizou seus estudos primários e secundários em Nova Lisboa (Huambo) e Sá de Bandeira (Lubango), seguindo para Portugal em 1947 para realizar seus estudos superiores. Durante muito tempo foi apresentado com o ideólogo do MPLA e ocupou a direção política do movimento (de 1960 a 1974, o Comitê Diretor) e, depois, do Estado-Partido (Comitê Central, desde 1974). A sua queda política no interior do MPLA ocorreu a partir de 1983, subsequente ao Maio de 1977, que marcou uma das crises mais profundas da história do movimento (MABEKO-TALI, 2018, p. 82, nota 20).
} 
colonizadores em relação aos colonizados" (MESSIANT, 2003, p. 230)22. Tempos depois, em uma carta a Lúcio Lara, datada de 29 de outubro de 1959, Viriato da Cruz ressaltou as diferenças entre a "organização de 'esquerda" de Angola e o PCP, a despeito dos interesses em comum "[...] entre o proletariado luso e o nosso povo sob o regime colonial luso" (CRUZ, 2017a, p. 155). Segundo Viriato,

Esses interesses comuns tornam possível e até desejável uma colaboração na luta. Em todo caso, nós compreendíamos que essa "luta" (no seu aspecto genérico) assumia na prática aspectos inconfundíveis. A nossa luta radica-se numa história africana, desenvolve-se num terreno africano, baseia-se fundamentalmente em massas populares africanas, com culturas africanas e não europeias; essa luta visa, no presente, liquidar o colonialismo luso. No futuro, tudo indica que o desenvolvimento dos nossos interesses económicos, políticos e culturais orientarse-á cada vez mais para o continente africano e menos para Portugal (CRUZ, 2017b, p. 155, grifo do autor).

Viriato inclusive afirmaria em um conhecido artigo, publicado em 1964, Angola: quelle indépendence..., que "O PCP não exerceu nenhuma influência relevante nem sobre a preparação, nem sobre o desencadeamento revolucionário angolano" (CRUZ, 1964, p. 10).

No entanto, o PCA, mesmo estabelecendo como objetivo a independência de Angola, provocou a resistência daqueles que apoiavam a luta pela libertação, mas nada queriam saber com o comunismo. Sendo assim, é criado o Partido da Luta Unida dos Africanos de Angola (PLUAA), com o intuito de garantir uma maior adesão (BITTENCOURT, 1997, p. 186).

É nesse contexto que Viriato da Cruz redige o Manifesto de 1956, que se constituirá no texto fundador do nacionalismo angolano e do próprio MPLA. Segundo Bittencourt (1997, p. 192), este Manifesto, que pertencia ao PLUAA, “[...]só em suas palavras finais conclama a população angolana para a criação de um amplo movimento popular de libertação de Angola. Esse trecho, portanto, teria servido de inspiração para o nome MPLA, só que bem mais tarde”. O texto, além

\footnotetext{
22 O PCP só reconheceria o direito à autodeterminação e à independência das colônias portuguesas em África em 1957, no seu V Congresso (INFORME..., 1957, p. 7). Rocha (2003, p. 81) ressalta que esse reconhecimento só se concretizaria em ações práticas a partir de 1962.
} 
de conter uma análise da situação das classes trabalhadoras de Angola, conclama a "luta revolucionária" levada a cabo por

[...] uma frente única de todas as forças anti-imperialistas de Angola, sem ligar às cores políticas, à situação social dos indivíduos, às crenças religiosas e as tendências filosóficas dos indivíduos, através portanto do mais amplo MOVIMENTO POPULAR DE LIBERTAÇÃO DE ANGOLA. [...] O movimento será a soma das atividades de milhares e milhares de organizações [...] que se criaram em toda a Angola. (CRUZ, 1956a, p. 8-9)

Michel Cahen (2013, p. 146), ao sublinhar o caráter embrionário desse documento na criação do MPLA, chama a atenção para o projeto por ele veiculado: "...um projeto de movimento popular de libertação de Angola como conceito, mas não proclama, nem anuncia que foi formada uma organização". Cahen, ao retomar uma hipótese apresentada pelo historiador René Pélissier, ressalta "que a ideia da frente de libertação alargada existia [...] no início do ano de 1956" (CAHEN, 2013, p. 144). De acordo com Pélissier,

O Manifesto de dezembro de 1956 lançado em Luanda pelos dirigentes do PLUAA não é mais do que um aceno às outras microformações clandestinas que eles perscrutam, para que elas se fundam em uma frente comum, na qual os quadros comunistas deverão exercer a preponderância que thes é atribuída pela sua preparação, pela sua disciplina e pela sua devoção à causa. [...] esse Manifesto [...] não é mais do que um programa de reagrupamento, cujos autores procuram não intimidar nenhuma das tendências existentes no seio do nacionalismo angolano como as que podemos encontrar em Luanda ${ }^{23}$. (PÉLISSIER, 1978, p. 245)

Segundo Pestana (2017, p. 4), o Manifesto de 1956 tem uma importância fulcral para o nacionalismo angolano, já que “[...] todas as organizações ulteriores ao PCA foram criadas à luz dos mesmos princípios [do Manifesto], sendo esta preocupação também enfatizada, do mesmo modo, no Manifesto do MAC [Movimento Anti-Colonial] 24". Ainda na visão de Pestana (2017, p. 1), "O Manifesto de 1956 faz parte do património político da esquerda revolucionária angolana”.

\footnotetext{
${ }^{23}$ Pélissier chega a esta conclusão mesmo que nessa altura não possuísse as fontes suficientes para determinar a data exata da criação do MPLA como estrutura organizada (CAHEN, 2013, p. 144).

${ }^{24} \mathrm{O}$ contexto do surgimento do MAC será abordado mais adiante.
} 
Retomemos aqui a crítica de Messiant (2008b, p. 192) à interpretação de Pacheco dos documentos dos arquivos da PIDE. Pacheco (1997, p. 33), por não ter encontrado um Manifesto datado de 1956 nesses arquivos, afirma a sua inexistência por considerar que "Não seria difícil para a PIDE apanhar aquele documento, tanto mais que os próprios serviços secretos estrangeiros, aliados da ditadura salazarista, se encarregariam disso". No entanto, o próprio Viriato, em uma carta a Lúcio Lara de 29 de outubro de 1959, refere-se à sua existência, bem como às suas diferentes versões:

Quanto ao programa [do MAC], estou de acordo em que se deva redigir outro, mas dentro da actual situação dos nossos problemas. Vou fazer um rascunho aqui. Enviar-to-ei depois. Em todo caso, pede a Paris que te envie cópias do programa que redigimos lá há dois $\operatorname{anos}^{25}$ e cópia do programa redigido em Angola e que vinha com os estatutos que já conheces. 0 Mário ${ }^{26}$ deve ter cópia deste último programa, e o Marcelo [Marcelino dos Santos] deve ter cópia do primeiro (CRUZ, 2017b, p. 159)

A carta de Viriato vem acompanhada de um comentário ulterior de Lúcio Lara: "Não me recordo deste programa de que fala Viriato. Será o Manifesto?..." (LARA, 2017, p. 159, nota 1).

Não temos aqui a intenção de discutirmos os pormenores do debate acerca da autenticidade do documento que se encontra na Associação Tchiweka de Documentação (ATD), em Luanda ${ }^{27}$. Interessa-nos sublinhar que o documento disponível na ATD é um texto manuscrito, do punho de Viriato da Cruz, sem título ou data (CRUZ, 1956a). De acordo com uma nota de esclarecimento da ATD (O MANIFESTO..., 2019a, p. 6), é possível que este texto seja de 1956, já que faz

\footnotetext{
${ }^{5}$ Durante a sua passagem por Paris, no final de 1957.

${ }^{26}$ Mário Pinto de Andrade (1928-1990) nasceu em Golungo Alto, Angola. Após concluir os estudos secundários em Luanda, vai para Lisboa e, como bolsista, ingressa na Faculdade de Letras (curso de Filologia Românica). Foi membro da Casa dos Estudantes do Império (CEI). Dirigiu as atividades do Centro de Estudos Africanos (CEA), das quais participavam Francisco Tenreiro, Agostinho Neto, Amílcar Cabral, Noémia de Sousa, dentre outros. O centro recebia a colaboração de outros angolanos, como Viriato da Cruz, António Jacinto e Luandino Vieira. Publicou o Caderno de Poesia Negra de Expressão Portuguesa. Dentre seus livros, destaca-se Origens do nacionalismo angolano. Muda-se para Paris em 1956, onde passa a trabalhar na revista Présence Africaine com Alioune Diop. Foi o primeiro presidente do MPLA (1960 a 1962) e da CONCP (Conferência das Organizações Nacionalistas das Colônias Portuguesas), a partir de 1961. Em 1974, funda com o seu irmão, Joaquim Pinto de Andrade, a "Revolta Activa", corrente de oposição à liderança de Agostinho Neto no MPLA que exige a democratização do regime.

${ }^{27}$ Acerca desta polêmica, consultar: O MANIFESTO... (2019a; 2019b).
} 
referência ao Congresso de Economistas "recentemente" realizado em Luanda, cuja data é setembro de 1955.

Se considerarmos o excerto da carta de Viriato citado acima, não seria descabido supor que este documento tenha sido redigido em Angola. Já na página eletrônica da Casa Comum, da Fundação Mário Soares (Lisboa), que alberga o Arquivo Mário Pinto de Andrade, encontra-se disponível uma cópia em papel químico do documento disponível na ATD, contendo um título "Manifesto do MPLA" e, ao seu final, uma data em francês, "Décembre 1956", ambos inseridos à mão e à tinta por Mário de Andrade (CRUZ, 1956b). Por fim, a Casa Comum também disponibiliza uma versão datilografada - e ligeiramente modificada deste Manifesto (CRUZ, 1956c). Supomos que esta seja a versão que fora datilografada em Paris, a qual se refere Viriato, já que uma das modificações feitas transparece a intenção de tornar o texto mais representativo do conjunto das colônias africanas de Portugal, e não apenas de Angola. No documento manuscrito (tanto no original, quanto na cópia) lemos a seguinte passagem: “A unificação das organizações faz-se, portanto, através de um certo número de ideias, de princípios de objetivos comuns a todas as organizações, comuns a todos os indivíduos angolanos organizados" (CRUZ, 1956a, p. 9; CRUZ, 1956b, p. 17). Já no documento datilografado, a passagem "angolanos organizados" foi suprimida (CRUZ, 1956c, p. 6).

\section{Fuga de Luanda}

Em 30 de setembro de 1957, fugindo da perseguição da PIDE ${ }^{28}$, Viriato deixa Luanda e passa rapidamente por Lisboa, onde se hospeda na casa do amigo Amílcar Cabral29. Importa esclarecer que a relação de amizade entre Viriato da Cruz e Amílcar Cabral teve início em Luanda. Como engenheiro agrícola na

\footnotetext{
${ }^{28}$ Nessa data, a delegação da PIDE de Luanda oficia à Direção de Lisboa, informando que "...a bordo do Paquete Uíge [...] viaja o nacional Viriato Francisco Clemente da Cruz que se encontra referenciado nos arquivos dessa direção" (PIDE, 1957 apud SILVEIRA, 2003, p. 5).

${ }^{29}$ Amílcar Cabral (1928-1973) nasceu em Bafatá (Guiné). Filho de pais cabo-verdianos. Realizou os estudos secundários em Mindelo (Cabo Verde), concluindo-os em 1948. Ao conseguir uma bolsa de estudos, ingressa no Instituto de Agronomia (Lisboa). Foi fundador do PAIGC (Partido Africano para a Independência da Guiné e Cabo Verde). É assassinado em 20 de janeiro de 1973, em Conacri.
} 
Sociedade Agrícola de Cassequel, Cabral desenvolveu trabalhos em cartografia de solos e de recuperação de terrenos salgados, bem como da "morte súbita" que acometia as plantações de café (SANTOS, 2014, p. 139). Entre os anos de 1955 e 1957, realizou diversas viagens à trabalho para Luanda, onde se deparou com um ambiente de discussão e contestação às questões coloniais, mesmo que disfarçado sob a roupagem de movimentos culturais. Também ocorrem nessa altura as fundações do PCA e, posteriormente, do PLUAA. Logo, Cabral, em suas estadias em Luanda, conviveu com diversos militantes nacionalistas e revolucionários, como Cândido Costa, Gabriel Leitão, Deolinda Rodrigues, Mendes de Carvalho e o próprio Viriato da Cruz.

Tomás Medeiro revela que foi em Angola que Cabral adquiriu a consciência acerca da necessidade de lutar pela independência da Guiné e de Cabo Verde, já que ele "[...] só começa a falar da independência de quando foi a Angola trabalhar em Cassequel" (MEDEIRO, 2004 apud SANTOS, 2014, p. 146); foi em Angola onde ele "perdeu as ilusões do solo e passou a perceber que o problema estava não no solo, mas na organização e no combate" (MEDEIRO, 2004 apud SANTOS, 2014, p. 146).

De acordo com o relato de Eduardo Macedo dos Santos ${ }^{30}$ a Edmundo Rocha, já em Lisboa Viriato organizou uma reunião com Lúcio Lara, Amílcar Cabral e o próprio Eduardo Macedo dos Santos para lhes expor a situação política de Angola, incentivando-os "[...] a organizarem-se em moldes africanos e a tornarem-se autónomos dos partidos da Oposição portuguesa e a mobilizarem os jovens estudantes" (ROCHA, 2003, p. 102)31. Viriato chega, pois, em Lisboa, "[...] com ideias mais articuladas e, sobretudo, mais concretas acerca do panorama político de Angola, do qual dava uma visão muito radical, sobre o caminho a seguir contra o regime colonial" (MABEKO-TALI, 2018, p. 102). Ainda segundo

\footnotetext{
${ }^{30}$ Eduardo Macedo dos Santos (1925-2001) nasceu em Malanje, Angola. Formou-se em medicina em Coimbra, Portugal. Integrou o núcleo lisboeta do MAC. Ainda em Lisboa, atuou politicamente junto a Agostinho Neto, Arménio Ferreira, Ivo Loio, entre outros. Foi membro do primeiro Comitê Diretor do MPLA e do CVAAR. Cardiologista, foi médico pessoal de Agostinho Neto

${ }^{31}$ Em uma carta a Lúcio Lara, datada de 22 de novembro de 1959, Viriato da Cruz, alegando existir um "aborrecimento dos amigos de Lisboa" quanto a ele, acusa-os de não terem visto que, "...cumprindo disciplinadamente, o que me fora ordenado na terra [Angola], a minha conduta tinha o fundamento que a busca das atividades lusas provou depois" (CRUZ, 2017b, p. 177, grifo de Lúcio Lara).
} 
Eduardo dos Santos - e contradizendo Lúcio Lara (2017, p. 42) ${ }^{32}$ - Agostinho Neto não teria participado dessa reunião, fato que impediu que Viriato o conhecesse. Anos depois, o próprio Viriato da Cruz afirmaria que ele e Neto só se conheceram pessoalmente mais tarde ${ }^{33}$, no Congo-Léopoldville ${ }^{34}$.

Viriato da Cruz viaja em seguida a Paris. Para esta viagem, consegue obter o passaporte no 14091/57, em 19/09/57, no Governo Civil de Lisboa ${ }^{35}$, o que significa que a PIDE ainda não o considerava um "elemento subversivo" (ROCHA, 2008, p. 135). Permanece várias semanas na capital francesa, compartilhando o quarto de Mário Pinto de Andrade. Durante essa curta estadia, Viriato passava as noites a estudar e a escrever, para dormir de dia, quando o seu amigo Mário de Andrade se levantava e saia para trabalhar como secretário de Alioune Diop, diretor da revista Présence Africaine (HORTA, 2010). Com a presença de Viriato da Cruz, é realizada, em Paris, em novembro de 1957, uma "Reunião de consulta e de estudo para o desenvolvimento da luta contra o colonialismo português", em que estavam presentes Mário de Andrade, Amílcar Cabral, Marcelino dos Santos ${ }^{36}$ e Guilherme Espírito Santo. Nesse encontro, discutiram a situação colonial, os meios para extingui-la e a conseguinte necessidade de criação de um organismo político anticolonial que deveria agrupar jovens africanos de todas as colônias

\footnotetext{
${ }^{32}$ A versão de Lara (1917, p. 42) desse suposto encontro é a seguinte: "Em Outubro de 1957 dá-se em Lisboa um acontecimento inesperado. Um dia alguém me comunicou que vira em Lisboa Viriato da Cruz, que eu não conhecia fisicamente, perto da casa de Amílcar Cabral. Fui encontrar - Amílcar e disse-lhe que alguém me comunicara ter visto Viriato da Cruz perto de sua casa e que eu nem acreditara porque não era possível que um dos que nós considerávamos dirigentes do exterior tivesse vindo a Portugal sem nos dar qualquer sinal ou sem nos procurar. Fiquei espantado quando Amílcar, algo hesitante, me confirma que o Viriato estava realmente em sua casa mas que, por razões conspirativas, lhe pedira total segredo... Fiz ver ao Amílcar a situação dúbia em que ele próprio se colocava como membro do Directório [do MAC] que tínhamos criado e convenci-o a falar com o Viriato para que se desfizesse a estranheza daquela situação, propondo-the um encontro pelo menos com alguns membros do Directório. Amílcar Cabral saiu-se bem dessa tarefa e o encontro com Viriato teve lugar em minha casa, com a presença de Neto e Amílcar".

${ }^{33}$ Esta afirmação de Viriato da Cruz ficou registrada na Ata da Reunião do MPLA de 12 de outubro de 1961, quando da primeira grande crise no seio do movimento. Ver: MPLA, 1962, p. 2.

${ }^{34}$ O Congo-Léopoldville, de colonização belga, atualmente República Democrática do Congo, cuja capital é Kinshasa, proclamou a sua independência em 30 de junho de 1960. O Congo-Brazaville, de colonização francesa, atual República do Congo, cuja capital é Brazaville, proclamou a sua independência em 15 de agosto de 1960. Para evitar confusões, sempre que nos referirmos a ambas as capitais, estas virão precedidas por um hífen e o nome do país.

${ }^{35}$ ANTT, PIDE, Viriato da Cruz, Proc. $.1153 / 51$, Doc. RC2110 74 Pa 35/Eu, doc. 2 a 4 (apud ROCHA, 2008, p. 135, nota 143).

${ }^{36}$ Marcelino dos Santos (1929-2020) nasceu em Lumbo, Moçambique. De Lisboa seguiu para Paris, para estudar na Sorbonne. Com Mário de Andrade e Guilherme Espírito Santos, coordenou o núcleo parisiense do MAC. Foi fundador da FRELIMO (Frente de Libertação de Moçambique).
} 
(ANDRADE, 1999, p. 141). Segundo o próprio Viriato, dessa reunião em Paris resultou um acordo quanto aos “...Estatutos, Programa, Declarações de Princípios e Resoluções..." (CRUZ, 2017b, p. 177) concernentes ao Movimento Anti-Colonial (MAC) que, a partir dessa reunião, seria criado mais tarde, em Lisboa, em 1959 (ROCHA, 2003, p. 117-118) ${ }^{37}$.

Entretanto, devido às precárias condições de sobrevivência em que se encontrava em Paris, Viriato viajou, em janeiro de 1958, a Liège, Bélgica, à procura de José Carlos Horta ${ }^{38}$, munido de uma carta de apresentação de Marcelino dos Santos. Viriato e José Carlos logo se tornariam amigos. Esta relação de amizade perdurou até o falecimento de Viriato da Cruz em Pequim, em 1973. Na residência de Horta aconteciam reuniões de estudos literários das quais Viriato participava. Foi durante essas reuniões que, segundo Horta, Viriato teve contato com as obras de Mao Tsé-Tung ${ }^{39}$. No entanto, importa lembrar que tanto Serrano (2012) como Pestana (2016), amparando-se na correspondência publicada por Salim Miguel (2005), particularmente em uma carta de António Jacinto, argumentam que o contato de Viriato da Cruz com as obras de Mao Tsé-Tung e de outros autores chineses se deu quando ele ainda se encontrava em Angola ${ }^{40}$. Como Viriato da Cruz e seu amigo, António Jacinto, compartilhavam os livros que liam $^{41}$, a hipótese de que aquele tivera contato, ainda em Angola, com as obras de Mao Tsé-Tung e de outros autores chineses é reforçada por uma carta de António

\footnotetext{
${ }^{37}$ E não em 1957, antes da chegada de Viriato em Lisboa, como alegou Lúcio Lara (ver nota 32, supra).

38 José Carlos de Oliveira Sousa Horta (1935-2020) nasceu em Inhamússua, Homoíne, Moçambique. Em dezembro de 1953, mudou-se para a Bélgica para cursar os estudos universitários. No verão de 1957, participou do Sexto Festival Mundial da Juventude e dos Estudantes, em Moscou, onde conheceu Marcelino dos Santos, Mário Pinto de Andrade e Aquino Bragança, que vinham de Paris e com quem estabeleceu contato. Foi, também, o idealizador da UGEAN (União Geral dos Estudantes da África Negra) e conselheiro do MPLA.

39 José Carlos Horta, comunicação pessoal, Lisboa, abril de 2019. Segundo Messiant (2003), em 2004, Horta lhe contara que já havia lido Marx, Engels, Lenin, Stalin e Mao em Moçambique (fato narrado pelo próprio Horta em seu currículo político, ainda inédito, cujas atividades são comprovadas por documentos da PIDE) e que emprestou esses livros à Viriato da Cruz, quando este se encontrava hospedado em sua casa.

${ }^{40}$ Em carta datada de 9 de outubro de 1955, António Jacinto faz o seguinte pedido a Salim Miguel: “De novo venho solicitar os seus amáveis préstimos. Necessito de Trente ans du parti comuniste (sic) Chinois por Hou Kiao-Mou e de How the tillers win back their land, por Hsiao Chien..." (JACINTO, 2005, p. 27).

${ }^{41}$ Em sua primeira carta a Salim Miguel (23 de outubro de 1955) publicada na coletânea, Viriato da Cruz assim a inicia: "Meu Caro Amigo. Conheço-o através de trabalhos seus publicados na Sul. E já estou ansioso por conhecê-lo melhor por intermédio de Velhice - livro que está sendo lido, neste momento, pelo meu amigo António Jacinto" (CRUZ, 2005, p. 38).
} 
Jacinto a Mário Pinto de Andrade, datada de 1o de fevereiro de 1952, em que Jacinto solicita a Mário que lhe enviasse as “...conferências de Mao-Tsé-Tung [...] E mais literatura similar..." (JACINTO, 1997, p. 193).

Contando com o apoio de estudantes amigos belgas e estrangeiros, Horta procurou encontrar meios de subsistência para Viriato permanecer em Liège, não logrando, porém, obter-lhe nenhuma bolsa de estudos. Ademais, naquela altura, os empregos formais na Bélgica estavam vedados aos estrangeiros, salvo nas minas de carvão, trabalho incompatível com a frágil condição de saúde de Viriato. Logo, durante o Carnaval de 1958, Viriato segue viagem pedindo carona na beira da estrada, rumo a Frankfurt, onde permaneceu durante todo esse ano vivendo na casa do casal Bouvier e apoiado pela família De Barry42, amigos de Mário de Andrade (ROCHA, 2008, p. 143). De Frankfurt, Viriato se muda, em 1959, para Berlim Oriental, a convite da União dos Escritores Alemães (da RDA) (ROCHA, 2003, p. 167). Horta relatou que Viriato chegou a enviar-lhe um manuscrito seu intitulado "A crítica à Ideologia do Colonialismo Português". Mais tarde, já em Conacri, desistiria de publicá-lo por considerá-lo tendencioso e ultrapassado. Infelizmente, segundo Horta (2010), este texto se perdeu. Durante esse período, Viriato também escreveu textos de denúncia do colonialismo português ${ }^{43}$, além de preparar, como já anunciamos, o Manifesto do MAC, inspirado no Manifesto de 1956 (ROCHA, 2008, p. 143).

A primeira viagem de Viriato da Cruz e alguns dos seus companheiros Mário de Andrade e Marcelino dos Santos - à China data de outubro de 1958,

\footnotetext{
42 Herbert de Bary e Erica de Bary (1907-2007) se casam em 1931, quando se mudam para Frankfurt. Durante a ocupação alemã, Erica vive em Paris, onde estabelece contato com escritores e políticos africanos, como Léopold Sédar Senghor e Jacques Rabemananjara que, posteriormente, visitam-na em Frankfurt. Janheinz Jahn e Senghor se conheceram, em dezembro de 1951, em sua casa. Em 1952, Erica viaja ao Marrocos, depois à Argélia e doze vezes, por períodos mais longos, ao Saara líbio, onde vive com famílias tuaregues, acompanhando-as, em uma ocasião, ao norte de Camarões. Em 1970, ela e seu marido viajam para Madagascar a convite do Ministro Jacques Rabemananjara. Erica de Bary era escritora e também editou o diário de expedição do explorador africano Erwin von Bary, traduzindo-o para o francês (Disponível em: https://second.wiki/wiki/erica de bary. Acesso em: 15 maio 2021).

${ }^{43}$ No início do mês de abril de 2019, tive o meu primeiro encontro com José Carlos Horta. Já na primeira visita que the fiz em seu apartamento em Algés, nos arredores de Lisboa, Horta - que se encontrava extremamente debilitado fisicamente e apresentava alguns lapsos de memória - permitiu-me digitalizar, em sua casa e sob a sua supervisão, bem como a do seu filho, José Daniel Horta, todas as cartas que Viriato da Cruz lhe havia enviado, bem como vários outros documentos, entre eles um artigo de Viriato da Cruz, publicado em alemão, em 1958, e intitulado: "Angola und der portugiesische Kolonialismus" (“Angola e o colonialismo português”).
} 
como membros do MAC. Após o primeiro Congresso da Organização de Escritores Afro-Asiáticos (OEAA), em Tashkent (Uzbequistão), realizam uma rápida viagem à antiga URSS (ANDRADE, 1997, p. 147-148), onde estabelecem contatos com membros de outras delegações africanas, como o poeta Nazim Hikemet, e com William Du Bois, um dos fundadores do Pan-Africanismo (ROCHA, 2008, p. 142). É, justamente, nessas circunstâncias que a delegação chinesa os convida para irem à China. Segundo o testemunho de José Carlos Horta ao seu amigo Edmundo Rocha, "Viriato ficou muito impressionado com a realidade chinesa e também com as teses da condução da revolução popular num país eminentemente rural e subdesenvolvido..." (ROCHA, 2008, p. 142). Esta informação é corroborada por um manuscrito de Viriato da Cruz intitulado Primeira impressão sobre a China. Transcrevo a seguir uma passagem desse escrito:

O provável é que eu tivesse visto primeiro campos, edifícios novos e montanhas da China; mas nada, porém, possui a força para me convencer que não foi o homem chinês que primeiro vi neste país - tão profunda e espantosa foi a impressão que colhi da atitude daquele.

[...]

Estou convencido de que o homem chinês com quem contacto todos os dias se desenvolveu muito mais do que a vida material da China, a qual venho constatando ter crescido, por sua vez, em ritmos admiráveis (CRUZ, 1960, p. 1).

Em março de 1959, Viriato da Cruz, Lúcio Lara e Mário de Andrade participam, em Roma, da 2a Conferência de Escritores e Artistas Negros. Nessa ocasião, Viriato apresenta o texto “Des responsabilités d'intellectuel noire”, em que critica a política colonial portuguesa de assimilação ${ }^{44}$, defendendo que a luta contra o colonialismo deveria se fundar na "unidade dos africanos" (CRUZ, 1959). Nessa ocasião, conhecem Frantz Fanon, líder da Frente de Libertação Nacional (FLN), Argélia, e conselheiro do Governo Provisório Revolucionário da Argélia

\footnotetext{
${ }^{44} \mathrm{O}$ regime de Indigenato foi aplicado tanto em Angola como em Moçambique e Guiné. No caso de São Tomé e Príncipe, aplicou-se o "Estatuto de cidadania" comum aos moradores da metrópole. Para que um "indígena" alcançasse o estatuto de assimilado, de acordo com as leis coloniais portuguesas, devia abandonar os seus "usos e costumes". Os requisitos que deviam ser reunidos por um indivíduo, os quais se mantêm desde o início do século XX até o final da década de 1950, eram: saber ler, escrever e falar português corretamente; ter meios suficientes para sustentar a família, ter bom comportamento, ter necessária educação e hábitos sociais de modo a poder viver sob a lei pública e privada de Portugal. Para mais detalhes, ver Macagno (2019).
} 
(GPRA). Nesse encontro, Fanon anuncia a Cruz, Lara e Andrade a disponibilidade da FLN em ajudar na formação político-militar de jovens quadros de Angola, garantindo-lhes a estadia em uma das bases da Frente na linha da fronteira entre Tunísia e Argélia. De acordo com Andrade,

A FLN estava interessada no alargamento do que se chamava o "campo anti-imperialista", num desencadear eventual de formas de luta - em particular a luta armada - no quadro da solidariedade activa com a FLN. O campo da NATO [North Atlantic Treaty Organization; OTAN - Organização do Tratado do Atlântico Norte] ficaria mais enfraquecido se outras lutas se desencadeassem noutros lugares. (ANDRADE, 1997, p. 150)

No entanto, a proposta de Fanon não vinga em virtude das prisões ocorridas em Luanda em meados de 1959, que interromperam os contatos dos jovens nacionalistas angolanos com os nacionalistas africanos do MAC, em Lisboa. A partir de então, Holden Roberto e a UPA passam a ser apoiados por Fanon (ROCHA, 2008, p. 146).

\section{O "Processo dos 50"}

Importa aqui uma referência a este período da história angolana. Justamente o ano de 1959 foi marcado por uma intensa mobilização política em Angola, que não se limitou à Luanda. Foram essas ações, consideradas subversivas pelo regime colonial, que motivaram as prisões ocorridas a partir de março de 1959. A ação da criação e distribuição de panfletos de caráter nacionalista se dava através de angolanos ligados a alguns grupos, como o Espalha Brasa, o Botafogo, o ELA (Exército de Libertação de Angola), o MIA (Movimento para a Independência de Angola), o MLA (Movimento de Libertação de Angola) (MATEUS, 2004; MEDINA, 2013; ROCHA, 2003). De acordo com Maria do Carmo Medina ${ }^{45}$ (2013), as prisões realizadas entre os meses de março e agosto de 1959 constituíram três processos.

\footnotetext{
Zillah Branco (2013) e Helena Pato (2017) apresentam-nos um breve comentário sobre o percurso profissional e político de Maria do Carmo Medina (1925-2014). Nascida em Portugal, formou-se na Faculdade de Direito de Lisboa. Nos anos de universidade, atuou politicamente na ala estudantil do Movimento da Unidade Democrática (MUD-Juvenil), ligado ao PCP. Realizou estágio obrigatório na Ordem dos Advogados com Avelino Cunhal, pai de Álvaro Cunhal, líder histórico do PCP. Deixou o país aos 25 anos de idade rumo a Angola, onde foi professora de
} 
O principal documento que dá início ao primeiro processo foi apreendido com José Manuel Lisboa, preso em 28 de março de 1959, no aeroporto de Luanda, quando retornava do Congo-Léopoldville. Nesse documento, intitulado "O nosso relatório para a conferência a realizar em Accra em março do corrente ano"46, "[...] comparavam-se as diferentes posições das potências colonizadoras, contrapondo-se a atitude do governo ditatorial de Salazar com a do governo belga que já reconhecera o direito do Congo ex-belga à independência" (MEDINA, 2013, p. 78).

O segundo processo se inicia com a prisão de Ilídio Machado, quando este se encontrava em Lisboa, em 27 de maio de 1959. Outras prisões ocorreram em Luanda com a apreensão de diversos documentos, listados por Medina (2013, p. 92-93): no navio African Dawn, atracado no porto de Luanda, foram apreendidos pela PIDE, junto ao tripulante cubano Francisco Javier Hernadez: uma carta endereçada a Kwame NKrumah (Gana), um envelope para Matias Miguéis (Ponte Negra), um exemplar do Jornal da Huíla de 24 de abril de 1959, 5 exemplares do panfleto "Manifesto Africano", assinado pelo MIA, 5 exemplares do panfleto "Aos angolanos", assinado por "Liberdade, Fraternidade e Prosperidade", 5 exemplares do panfleto "Aos militares Angolanos", assinado pelo MIA, uma folha endereçada a Viriato da Cruz, uma fotocópia do Tratado de Simulambuco, uma carta para David Nasser, uma carta endereçada à escritora brasileira Raquel de Queiroz, aos cuidados da revista "O Cruzeiro", assinada pelo MIA.

Com André Franco de Sousa, foram apreendidos os seguintes textos não assinados, mas que "[...] revelam-se de elevado valor para uma avaliação da real situação da exploração económica que se vivia no período colonial" (MEDINA,

Liceu até lograr abrir o seu escritório de advocacia (o primeiro aberto por uma mulher em Angola) no primeiro andar do prédio da emblemática Livraria Lello (lugar de tertúlias, discussões e resistência). Nele, passou a representar, junto às autoridades administrativas, "[...]funcionários angolanos relegados às mais baixas categorias de trabalho, a defender o direito de propriedade das famílias esbulhadas pelo poder colonial e, a partir de 1959, a defender os presos políticos e os que voltavam dos campos de concentração" (BRANCO, 2013, p. 13).

${ }^{46}$ A I Conferência dos Povos Africanos foi realizada em 1958, em Acra, capital de Gana, que conquistara a sua independência em março de 1957. O encontro foi liderado por Kwame Nkrumah, pensador, político pan-africanista e primeiro-ministro de Gana, e presidida por Tom Mboya, secretário-geral da Federação do Trabalho do Quênia. Entre as resoluções dessa Conferência, destaca-se o reconhecimento de "...que apenas a realização da independência política completa permitirá aos povos da África resolverem seus múltiplos problemas que são, na sua maioria, herdeiros do colonialismo e do imperialismo" e o compromisso em "[...] ajudar todos aqueles que combatem e através de todos os meios". (RESOLUTION..., 1959, p. 4). 
2013, p. 93): "Industrialização de Angola e a Situação da Nova Classe Operária", cuja autoria o pesquisador Nelson Pestana atribui a Viriato da Cruz (PESTANA, 2016; 2017) ${ }^{47}$, "Situação do Pescador Indígena", "O contrato"48. Esses documentos nos dão uma ideia da multiplicidade de grupos nacionalistas que agiam no interior de Angola, bem como da capacidade de articulação que possuíam para se comunicarem com os nacionalistas e apoiadores que se encontravam no exterior.

Por fim, o terceiro processo se inicia com mais uma série de prisões de nacionalistas, dentre eles, José Mateus Vieira da Graça, mais conhecido como Luandino Vieira.

Medina ainda nos chama a atenção para o fato de a maioria desses nacionalistas terem sido submetidos a torturas físicas e psicológicas e que a distribuição dos presos em três processos distintos seguiu um critério racista e regional: "[...] um de presos predominantemente de raça negra, outro predominantemente de mestiços e o terceiro com a maioria de brancos!" (MEDINA, 2013, p. 112). Ainda quanto ao objetivo de dividir os presos em três processos distintos, Medina argumenta que o regime colonial pretendia que o caso passasse "[...] mais despercebido dentro e fora do País, do que teria ocorrido caso levassem as dezenas de réus de uma só vez a tribunal, desmascarando a tese de 'bondade' do sistema de integração colonial cujo sucesso era apregoado pelo regime" (MEDINA, 2013, p. 112).

No entanto, o relato sobre as circunstâncias que envolveram esses três processos, de autoria de Viriato da Cruz e Mário de Andrade, acabou por publicizar uma visão unificada dessas acusações. Este relato contou com a colaboração do irmão de Mário de Andrade, o padre Joaquim Pinto de Andrade, que se encontrava em Luanda. Foi através da correspondente francesa

\footnotetext{
47 Segundo Pestana (2017, p. 1, nota 1), "Este texto, embora não esteja assinado, é facilmente atribuível a Viriato da Cruz pelo seu conteúdo e pelo facto de ter uma emenda à mão, na página 5 do documento, onde se reconhece a caligrafia inconfundível de Viriato da Cruz e ainda pelo facto do Manifesto de 1956 se referir, nos mesmos termos, ao chamado 'condicionamento industrial' da metrópole como obstáculo ao desenvolvimento da colónia. Este estudo não estando datado deve ter sido escrito em meados de 1955, pois as suas referências e indicadores económicos e sociais, retirados de documentos oficiais, reportam-se ao quinquénio 1950-1954".

${ }^{48}$ Os textos podem ser consultados em Medina (2013, p. 361-368, Anexo 17).
} 
destacada para Angola do jornal Le Monde, Suzanne de Lusignan ${ }^{49}$, que Joaquim conseguiu enviar ao seu irmão fotos da maioria dos presos políticos ${ }^{50}$. A publicação da brochura com os relatos e as fotos ocorreu em Liège, Bélgica, sob a responsabilidade de José Carlos Horta. Conhecido como o "Processo dos 50", esta publicação teve o papel de denunciar internacionalmente o que se passava em Angola. Horta assim narra o processo de elaboração e publicação desse documento:

Reuni uma comissão de personalidades belgas de vários quadrantes políticos, para editar o livrinho La Répression Colonialiste en Angola, Le Procès des Cinquante, denunciando a prisão de nacionalistas em Luanda ${ }^{51}$. Este livrinho continha uma introdução não assinada de Viriato da $\mathrm{Cruz}^{52}$, o texto assinado de Mário Pinto de Andrade, ilustrado por fotografias dos presos políticos, que the tinham sido enviadas de Luanda, pelo irmão Abade Joaquim Pinto de Andrade e vários outros documentos. $O$ livrinho precisava dum título [...]. O autor do título foi Marcel Levaux, um dos editores, dirigente da Juventude Comunista Belga, que pragmaticamente contou os retratos dos presos e se inspirou do nome dum processo político, que tinha decorrido na Bélgica e era designado pelo número de réus. O processo de Luanda passou a ser conhecido, na história, como "Processo dos Cinquenta" tradução do título do livrinho. (HORTA, 2010, p. 14, grifo do autor) ${ }^{53}$

Na introdução ao "livrinho" referida por Horta, Viriato (1960) faz uma crítica veemente ao Regime de Indigenato e ao trabalho forçado nas colônias portuguesas, bem como à violenta repressão da ditadura salazarista sobre os

\footnotetext{
49 Suzanne de Lusignan publicou uma reportagem no jornal Le Monde, em 11/02/1960, intitulada: "Province portugaise au delà de l'Équateur: l'Angola ressente les premiers symptômes de la fièvre nationaliste africaine". O artigo digitalizado encontra-se disponível na página eletrônica da ATD (Associação Tchiweka de Documentação): https://www.tchiweka.org/imprensa/0551000012. Acesso em: 08 out. 2021. Para uma análise deste e de outros artigos publicados no Le Monde sobre o Estado Novo e o colonialismo português, ver Nunes, 1995.

50 Ver, a esse respeito, carta de Mário de Andrade de 07 de março de 1960 (ANDRADE, $2017 a$, p. 313-314).

51 Os editores reunidos por Horta eram Marcel Levaux (Charette); Jean Godin (Chênée); Jacques Yerna (Liège) e Daisy Lenaerts (Fléron).

52 Em carta a Lúcio Lara de 13 de março de 1960, Mário de Andrade relata que pediu a Viriato da Cruz que redigisse para a brochura "[...] duas páginas sobre o significado político da participação de representantes de movimentos angolanos na conf. de Túnis” (ANDRADE, 2017b, p. 336). Em carta de 17 de março de 1960 intitulada "Caros amigos", Viriato envia uma cópia da referida introdução (CRUZ, 2017f, p. 337); na carta subsequente à Lúcio Lara e Amílcar Cabral, de 18 de março de 1960, Viriato, ao discutir a validade da publicação do Manifesto do MAC mesmo após a sua dissolução, cita uma passagem da sua introdução à brochura: "'Outro importante acontecimento, êxito do MAC, foi a constituição da FRAIN, formada pelo PAI e pelo MPLA, e em cujo seio o MAC se dissolveu [...]'”. (CRUZ, 2017g, p. 349).

53 Medina (2013, p. 109) também se refere à colaboração de Joaquim Pinto de Andrade, “...que enviou para fora de Angola o relato do que se passava com a prisão dos patriotas angolanos...”.
} 
povos colonizados através da sua polícia política. Apresenta, ainda, um pequeno histórico da luta nacionalista angolana, desde as mobilizações no interior das associações culturais - luta denominada por Viriato reformista - até a criação do MAC, do PAI, do MPLA e da Frain (no interior da qual o MAC se dissolveu), ou seja, da luta revolucionária contra o colonialismo português.

\section{Criação do MPLA}

Quando da // Conferência dos Povos Africanos, que ocorreu entre 25 e 30 de janeiro de 1960, em Túnis, é formada a Frente Revolucionária Africana para a Independência Nacional das colónias portuguesas (Frain), que substitui o primeiro movimento, o MAC. Mas em 1959, Viriato já teria concluído, como bem observa Edmundo Rocha (2008, p. 147), que "[...] a etapa de grupos e de movimentos plurinacionais já estava ultrapassada, e que havia chegado o momento de se criarem organizações nacionais".

A Frain pode ser considerada, citando Mário de Andrade (1997, p. 156), como "[...] o núcleo dirigente do bureau, ou dos bureaux exteriores ao MPLA, de um lado, e do PAIGC [Partido Africano da Independência da Guiné e do Cabo Verde]", cujos dirigentes eram Amílcar Cabral, Viriato da Cruz, Lúcio Lara, Hugo Azancot de Menezes e o próprio Mário de Andrade. "É a declaração de compromisso assinado em 31 de janeiro por Lúcio Lara e Viriato da Cruz (Frain e MPLA), Holden Roberto (UPA), Amílcar Cabral (Frain e Partido Africano da Independência - PAI) e Hugo de Menezes (Frain) que marca a fundação oficial do MPLA" em Túnis, em $1960^{54}$ (BITTENCOURT, 1997, p. 196). Edmundo Rocha corrobora este fato ao sublinhar que "É neste congresso que, pela primeira vez, aparece, publicamente, na arena internacional, o nome de Movimento Popular de Libertação de Angola MPLA - por iniciativa de Viriato da Cruz" (2008, p. 148). O MPLA é, pois, oficialmente criado no exterior, em Túnis (Tunísia), agindo primeiro em Conacri (capital da Guiné) e mais tarde no Congo-Léopoldville.

\footnotetext{
54 Uma versão da "Declaração de Compromisso", que se encontrava Arquivo Lúcio Lara, foi reproduzida por Bittencourt (1997, p. 201-202) no final do seu artigo sobre a criação do MPLA. Atualmente, a maior parte do Arquivo Lúcio Lara se encontra digitalizada na página eletrônica, recentemente disponibilizada, da Associação Tchiweka de Documentação (ATD): https://www.tchiweka.org/. Parte dessa documentação se encontra publicada em LARA (2017, 2006, 2008). A transcrição desse documento também pode ser consultada em Lara (2017, p. 270-271) e a digitalização do seu original está disponível em: https://www.tchiweka.org/documento-textual/0010000028. Acesso em 8 out. 2021.
} 
Lembremos que a versão oficial da criação do MPLA estabelece a data de 10 de dezembro de 1956, em Luanda, após a unificação do PLUAA com outros grupos nacionalistas. De acordo com Bittencourt (1997, p. 186), “[...] as narrativas desencontradas estão relacionadas à disputa entre a União das Populações de Angola (UPA) e o MPLA visando obter maior legitimidade e os possíveis apoios de aliados internacionais".

Em uma entrevista a Christine Messiant, o próprio Mário de Andrade assim justifica a antecipação da data da criação oficial do MPLA:

Temos de considerar que, na época, não se estava escrevendo história, travava-se uma luta política; é nesse quadro que devemos situar o que se disse. Nunca se mentiu de verdade, mas não se disse a verdade. Mas, dever-se-ia considerar os problemas que tínhamos na época com a UPA. Dizer que o MPLA existia, que tinha uma organização séria em Angola, era para o MPLA uma questão de vida ou morte. (MESSIANT, 2008b, p. 106-107)

Ainda em 1960, o núcleo dirigente do Frain se instala em Conacri (Guiné), onde se organiza o primeiro Comitê Diretor do MPLA. Hugo Azancot de Menezes ${ }^{55}$, que já se encontrava em Conacri desde agosto de 1959, onde atuava como médico no Hospital Balley (MENEZES, 2018, p. 81; 97), ganhou “[...] a confiança dos dirigentes guineenses e a promessa do acolhimento dos líderes das colónias portuguesas" (ROCHA, 2008, p. 149). É em virtude da atuação de Azancot de Menezes, que logra reunir condições materiais, que os nacionalistas angolanos, bem como suas respectivas esposas que se encontravam na Alemanha e em Paris, são acolhidos em Conacri, em sua casa, nos primeiros tempos (ROCHA, 2003, p. 169). Em seu livro de memórias, Azancot de Menezes relata da seguinte maneira a convivência, em sua casa, com Viriato da Cruz:

Mal chegou à Guiné, Viriato lançou-se ao trabalho. [...] Era um trabalhador incansável, sempre atento, metódico e disciplinado. A qualquer hora do dia ou da noite, lá estava ele debruçado sobre uma das suas agendas, tomando notas, rascunhando documentos, escrevendo à máquina e pondo em dia a sua volumosa correspondência. [...]. Recordo-me de Viriato sentado à

\footnotetext{
${ }^{55}$ Hugo Azancot de Menezes nasceu em São Tomé em 2 de fevereiro de 1928. Filho do médico Ayres de Menezes. Junto com o seu irmão, Óscar, teve uma participação ativa na Casa dos Estudantes do Império (CEI) em Lisboa, nos anos de 1950. Sobre o seu percurso intelectual e político, consultar Menezes (2018).
} 
mesa da sala de jantar a redigir e dactilografar o projecto dos Estatutos e o Programa do MPLA que submeteria depois à discussão do Comité Director numa das suas reuniões; ou a desenhar a bandeira do MPLA [(IMAGEM 1)] ou o emblema do Movimento [(IMAGEM 2)]. Dos emblemas inicialmente produzidos, (penso que na RDA), as mãos que seguravam o facho eram claras de mais ou menos cor branca. Foi, portanto, necessário mandar proceder à devida correcção, mudando a cor. (MENEZES, 2018, p. 105)

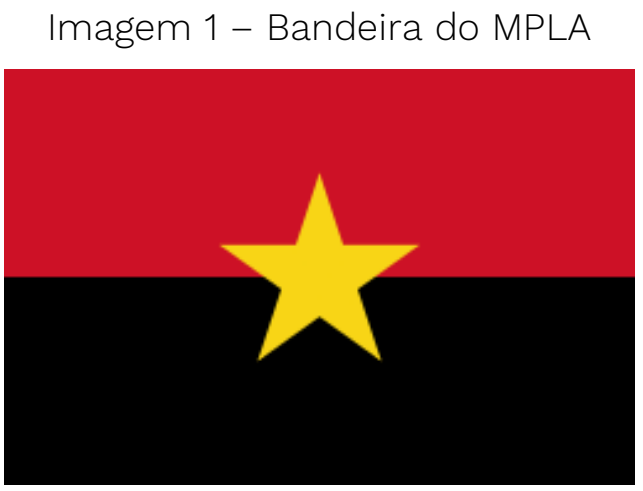

Fonte:https://pt.m.wikipedia.org/wiki/Ficheiro:Movimento_Popular_de_Liberta\%C3\%A7 \%C3\%A3o_de_Angola_(bandeira).svg. Acesso em: 13 abr. 2021.

Imagem 2 - Emblema do Movimento

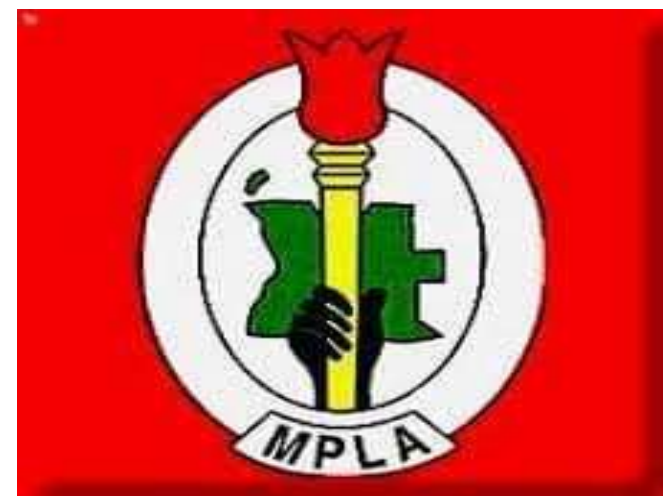

Fonte: http://manmessias21.blogspot.com/2013/02/fatos-historicos-importantes-parao-dia.html. Acesso em: 13 abr. 2020.

Maria de La Salete Guerra de Menezes confirma a versão do seu marido, Hugo Azancot de Menezes, e nos fornece mais algumas informações sobre a importância de Viriato da Cruz na criação do MPLA:

O Viriato foi o cérebro do MPLA. A ele se deve tudo. As bandeiras, os estatutos, tudo. Foi ele quem fez tudo. Portanto, ele foi o grande cérebro do MPLA. Eu lembro-me que ele vivia em minha casa, passava noites sentado a fazer tudo, os estatutos, tudo, tudo, as 
bandeiras... Bom, ele escrevia, apagava, rasgava... E então, meu marido ia todas as manhãs, quando se levantava, ao cesto que ficava ao pé dele [de Viriato] para apanhar tudo o que ele fazia e o que rasgava. Ele ficou hospedado em minha casa, em Conacri. Passava noites em claro. Ele quem fez tudo. Se disser o contrário, estou a mentir. Fez os Estatutos, a bandeira do MPLA, a bandeira da OMA [Organização da Mulher Angolana] [(IMAGEM 3)], a bandeira da Juventude [JMPLA] [(IMAGEM 4)], os fachos, os emblemas, ele quem fez tudo. Ele quem desenhou tudo. Ele quem era o cérebro ${ }^{56}$.

Imagem 3 - Bandeira da OMA

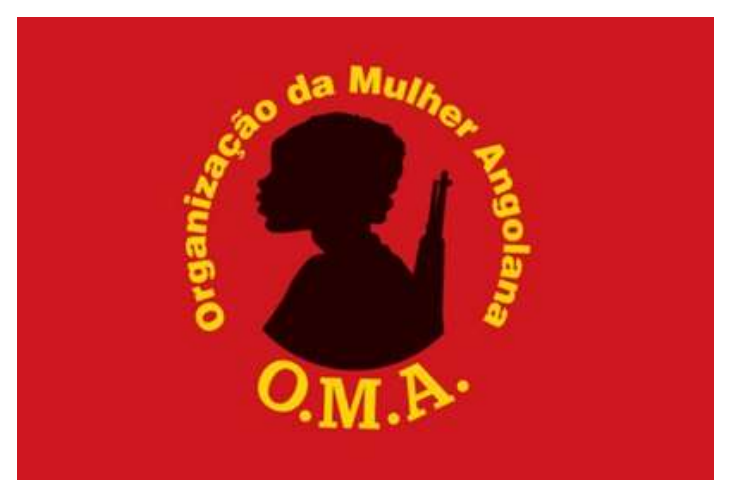

Fonte: https://www.portaldeangola.com/2015/11/02/oma-consternada-com-a-morte-damilitante-maria-judite-santos/. Acesso em: 13 abr. 2020.

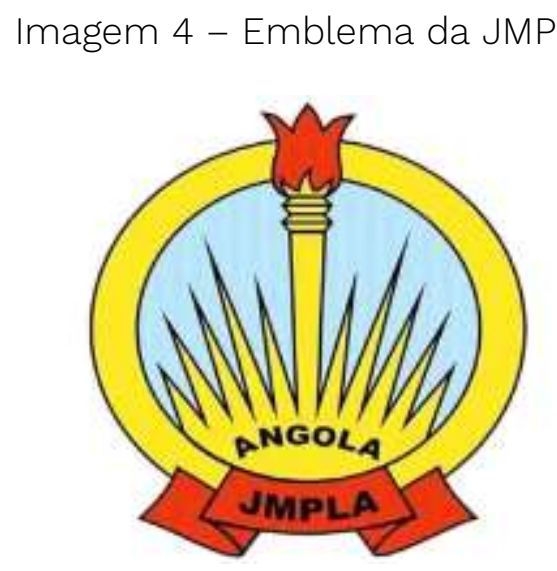

Fonte:

https://www.facebook.com/jmpla.cazenga/photos/a.725667674214174/3562583760522537/. Acesso em: 13 abr. 2020.

Já seu filho, Ayres de Menezes, em uma conversa com a mãe, lembra-se de ela the contar que a caixa postal da casa onde viviam era utilizada como endereço oficial do MPLA; que Viriato, durante a estadia em sua casa, dormia

56 Maria de La Salete Guerra de Menezes, comunicação pessoal através do WhatsApp, 13 abr. 2020. 
embaixo de uma mesa, sobre uma esteira de palha e protegido por um mosquiteiro (IMAGEM 5); e que a Sra. Salete cozinhava para todos os dirigentes do MPLA que viviam em sua casa (IMAGEM 6) ${ }^{57}$.

Imagem 5 - "Viriato da Cruz no exílio em Conakry (1960)"

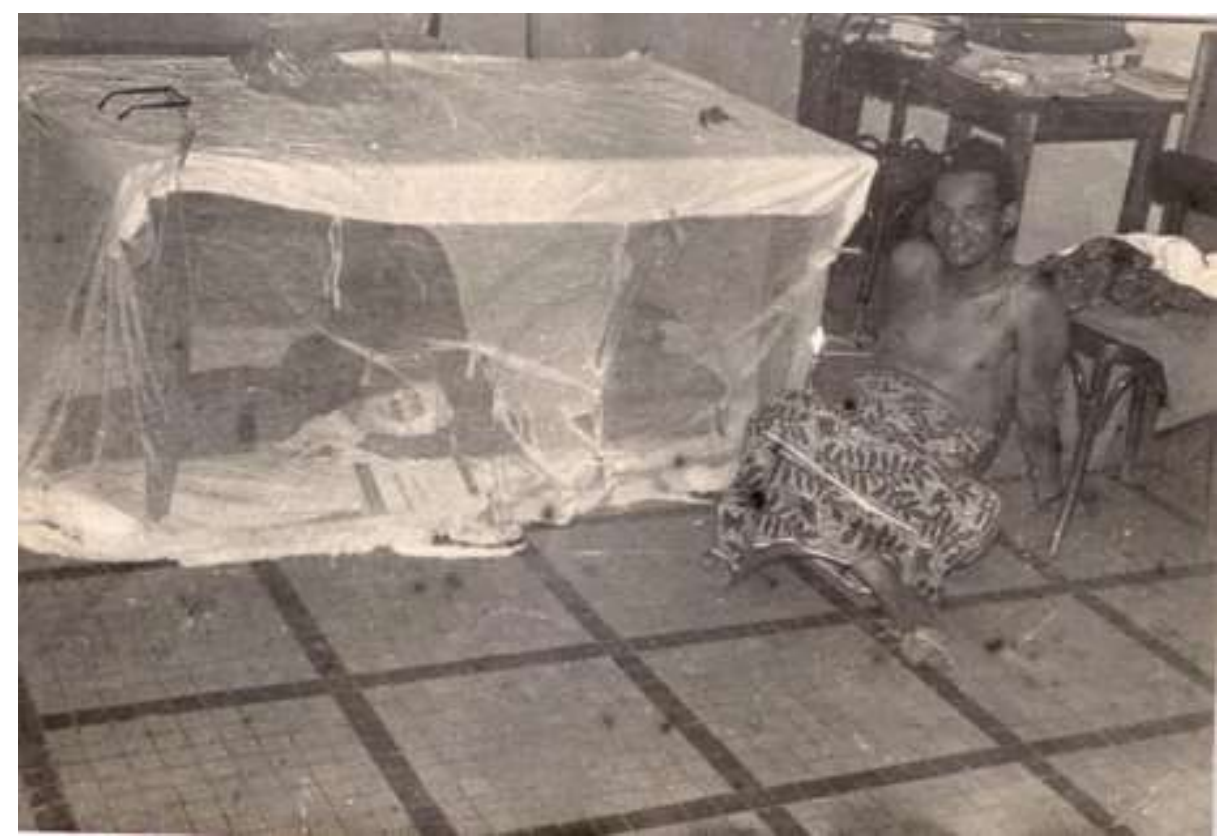

Fonte: Arquivo Lúcio Lara. Disponível em: https://www.tchiweka.org/fotografia/1007010017. Acesso em: 4 out. 2021.

Imagem 6 - Recado de Viriato da Cruz a Hugo Azancot de Menezes em Conacri58

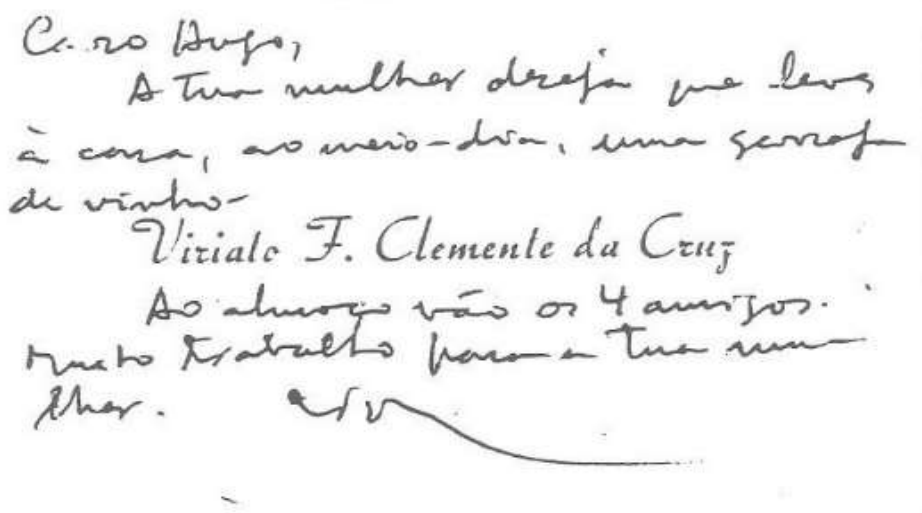

Fonte: Arquivo pessoal - Hugo Azancot de Menezes

Entre 11 e 15 de abril de 1960 se deu em Conacri a 2a Conferência de Solidariedade dos Povos Afro-Asiáticos. Em nome da delegação de Angola, Viriato

\footnotetext{
${ }^{57}$ Ayres de Menezes, comunicação pessoal através do WhatsApp, em 3 abr. 2020.

58 "Caro Hugo, a tua mulher deseja que leves à casa, ao meio-dia, uma garrafa de vinho. Ao almoço vão os 4 amigos. Muito trabalho para a tua mulher. vC”.
} 
fez uma intervenção denunciando uma repressão sangrenta do exército português a insurreições em Luanda e Catete. Denunciou, ademais, o envenenamento das populações africanas por "agentes ou aliados do colonialismo português". E declarou que a obtenção da independência não podia mais se restringir a métodos pacíficos de luta (CRUZ, 2017d, p. 368). Tais declarações seriam confirmadas por um "Apelo do MINA", recebido por Viriato em 2 de maio de 1960 (LARA, 2017, p. 293-300). Apesar de não concordar com as datas dessas insurreições, o historiador René Pélissier (1978, p. 308) afirma que foi a “[...] primeira repressão militar - e não policial - conhecida em 1960" em Angola e que a motivação foi "[...] mais política que econômica"59.

Em junho de 1960 é estruturado, em Conacri, o primeiro Comitê Diretor do MPLA. Viriato da Cruz assume o cargo de secretário-geral do MPLA e Mário de Andrade, o de presidente.

Agostinho Neto, que retornara à Luanda em dezembro de 1959, é convidado em março de 1960 pelos fundadores do MINA ${ }^{60}$ para assumir a primeira presidência desse movimento, o que viria a acontecer no mês seguinte (MABEKO-TALI, 2018, p. 117).

Segundo o relato de Lúcio Lara, Agostinho Neto, estando a par das ações dos nacionalistas no exterior, enviou Manuel Pedro Pacavira ao Congo-Brazaville para se encontrar com Lara. Nesse encontro, ocorrido em abril de 1960, Lara the transmitiu as diretivas dos membros do MPLA no exterior para que ocorresse a unificação das organizações interiores sob a sigla do MPLA ${ }^{61}$ (LARA, 2017, p. 371; MABEKO-TALI, 2018, p. 109).

Após o retorno de Pacavira a Luanda, e em uma reunião ocorrida em maio de 1960, Neto propôs a dissolução do MINA e a sua transformação em MPLA. No

\footnotetext{
59 Pélissier (1978) menciona essas revoltas, mas não indica suas datas precisas. No entanto, em virtude de uma "Informação privada de fonte não divulgável recolhida em Sá de Bandeira em 1o de setembro de 1966” (1978, p. 306, nota 24), nega que tenham ocorrido no mês de março, tal como divulgaram em diversos jornais e conferências dois membros do American Committee on Africa (ACOA), Frank Montero e William X. Scheinman (as reportagens são citadas em cartas de Lúcio Lara, 2017, p. 326; Viriato da Cruz, 2017e, p. 332 e Mário de Andrade, 2017b, p. 335, quem, inclusive, faz referência ao seu encontro com Frank Montero em Paris).

60 O MINA foi fundado entre abril e maio de 1959 por Cândido Fernando da Costa e Bernardo Silas, que haviam conseguido escapar, em 1959, das prisões efetuadas pela PIDE que culminaram no Processo dos 50 (MABEKO-TALI, 2018, p. 83).

${ }^{61}$ Um sumário desse encontro, datilografado por Lúcio Lara, pode ser consultado em Lara, 2017. p. 375-377.
} 
entanto, em 8 de julho de 1960, apenas um mês depois da fundação do MPLA no interior, Neto é preso com outros nacionalistas e deportado à Portugal62. A criação do MPLA em Luanda ocorreu, pois, após a criação do MPLA exterior. A Agostinho Neto foi destinado o cargo de Presidente de Honra do MPLA.

É curioso notar que no relato de Mabeko-Tali (2018), o Comitê Diretor do MPLA já estaria estruturado quando do encontro entre Lara e Pacavira no CongoBrazaville, em abril de 1960. No entanto, em uma carta a Lúcio Lara, datada de 1 de julho de 1960, quando este se encontrava em uma missão em Acra (Gana), Viriato da Cruz the comunica a prisão de Neto (CRUZ, 2017h, p. 399) e, em carta de 11 de julho de 1960, informa-lhe sobre a decisão de estruturação do Comitê Diretor provisório do MPLA: “Devo informar-te do seguinte: Foi decidido dar uma estruturação provisória do MPLA. A estruturação definitiva será feita brevemente em reunião alargada, possivelmente em Leo, onde grande número de nós deverá estar dentro de pouco" (CRUZ, 2017i, p. 404).

O que esses documentos transparecem é que a intenção dos membros do MPLA em Conacri era de que o MPLA do interior tivesse a preponderância na organização da luta pela libertação. Em virtude da prisão de Neto e de outros nacionalistas (entre eles, o padre Joaquim Pinto de Andrade) e da independência do Congo Belga (Congo-Léopoldville) em 30 de junho de 1960, assim comenta mais tarde Lara sobre o que the fora comunicado por Viriato da Cruz:

Tudo isso [os acontecimentos] explica de forma sábia e oportuna a decisão de criar o Comité Director provisório em Conakry, anunciado na carta de Viriato de 11.07.60, na certeza de que as últimas prisões de Luanda iriam decapitar a direcção do interior e que era preciso que a embalagem que se estava a tomar não parasse, mesmo com as hesitações dos países de quem se esperava uma solidariedade activa, o que não aconteceu (LARA, 2017, p. 398, grifo do autor).

De qualquer maneira, o pequeno lapso com as datas não compromete as conclusões as quais Mabeko-Tali (2018, p. 115-116) chegou: 1. Por um lado, os membros do MPLA em Conacri visavam resolver a questão da unificação das duas alas (interior e exterior) antes de passar às ações armadas e, 2. Por outro, era necessário lograr uma grande mobilização da opinião internacional

\footnotetext{
62 Para uma análise mais detalhada da formação do MPLA, consultar os trabalhos pioneiros de Pacheco (1997); Bittencourt (1999; 2002) e Mabeko-Tali (2018).
} 
concernente à realidade angolana, a fim de angariar os apoios necessários na luta contra o regime colonial. Era preciso, pois, combater a versão portuguesa de que reinava em Angola e nas demais províncias ultramarinas ${ }^{63}$ "...uma situação de harmonia e de integração social pacífica entre colonos e colonizados”.

Segundo Mário de Andrade (1997, p. 160), a direção do MPLA, com o objetivo de ampliar o campo dos aliados, dirige-se, junto com a direção do PAIGC, às embaixadas da antiga URSS e da República Popular da China, a fim de solicitar meios financeiros e materiais para criar as condições para uma ação que incluísse a luta armada. É a embaixada da China que acolhe a solicitação do grupo, sugerindo aos seus integrantes uma viagem a Pequim. Portanto, Viriato da Cruz viaja à China pela segunda vez. Nessa ocasião, é acompanhado por Amílcar Cabral e Eduardo dos Santos, todos, na altura, como dirigentes da Frain ${ }^{64}$. Segundo Mário de Andrade, a partir dessa data, Pequim começa a ajudar o MPLA:

[...] esta viagem à China foi determinante para o que ia se seguir; determinante, primeiro, no quadro da preparação, visto que os próprios dirigentes se submeteram a uma preparação armada. Altos responsáveis, ligados à Grande Marcha e à luta armada, à revolução chinesa, deram verdadeiros cursos de formação sobre a guerra de guerrilha a Amílcar Cabral, Eduardo dos Santos e Viriato da Cruz. [...] os dirigentes assimilaram pela primeira vez as técnicas de guerrilha. (ANDRADE, 1997, p. 161)

A China também forneceu uma ajuda financeira substancial. "Na época", relata Mário de Andrade, "a ajuda dava-se em notas de dólares. Recordo-me, eram notas de vinte dólares, que se transportavam nos bolsos dos sobretudos [...]. Viriato da Cruz, responsável do MPLA, “[...] chegou com os maços de vinte dólares, que foram suficientes para alimentar o nosso movimento durante algum tempo - para fazer a subversão geral e custear as nossas viagens, etc" (ANDRADE, 1997, p. 162). Naquela altura, os dirigentes do Frain e do MPLA

\footnotetext{
${ }^{63}$ De acordo com Macagno (2019, p. 124), “[...] em 1951, em virtude de uma proposta de revisão do Acto Colonial, no seio da Assembleia Nacional, é aprovada a Lei n.o 2048, de 11 de Junho de 1951. Assim, o termo 'Império Colonial Português' é substituído por 'Ultramar Português' e a nomeação 'colónias' cede lugar ao termo 'províncias ultramarinas'”. Esta mudança, que se cristaliza na "[...] Lei Orgânica do Ultramar Português, aprovada na Lei n.․ 2066, de 27 de Junho de 1953" procurava "[...] reforçar o princípio de unidade política entre metrópole e Ultramar [...]" e "[...] neutralizar as crescentes pressões da ONU a favor dos territórios ainda sem governo próprio".

${ }^{64}$ Messiant (2003, p. 220; 236) defende que o contato de Viriato com a obra de Mao Tsé-Tung, ocorreu nesse período, ou seja, entre 1959-1960
} 
buscavam se afirmar perante à UPA, que já havia conquistado espaço no campo pan-africano e africano, tanto "moderado" quanto "radical", além de se beneficiar do apoio americano (MESSIANT, 2003, p. 222) ${ }^{65}$.

\section{Congo, CVAAR e a crise no seio do MPLA ${ }^{66}$}

O início do ano de 1961 assinala uma mudança nos rumos dos movimentos nacionalistas em Angola e na forma da luta anticolonial adotada pelo MPLA. Esse ano é marcado pela explosão da revolta colonial em Luanda, em 4 de fevereiro e outra, mais ao Norte do país, em 15 de março67, ambas assumidas, respectivamente, pelo MPLA e pela UPA. O objetivo do MPLA era a aproximação geográfica com as fronteiras de Angola. De acordo com Mabeko-Tali (2018, p. 126), o Comitê Diretor, ainda em Conacri, havia submetido a Patrice Lumumba, então primeiro-ministro da República do Congo-Léopoldville, o seu projeto de se instalar naquele país que há pouco havia declarado a sua independência da Bélgica. A reposta de Lumumba, que estava de passagem por Conacri, era de que o MPLA deveria se integrar à UPA para que ambos os movimentos coordenassem a luta armada. Após o assassinato de Lumumba, em janeiro de 1961, o governo de Cyrille Adoula acatou o pedido do MPLA.

O Comitê Diretor do MPLA se transfere para o Congo-Léopoldville em setembro de 1961, ou seja, meses depois das revoltas acontecidas em Luanda e no norte de Angola. Em virtude do acirramento da repressão colonial portuguesa, chegam ao Congo milhares de refugiados angolanos, onde é organizado o CVAAR (Corpo Voluntário Angolano para a Assistência aos Refugiados), operação liderada pelos médicos Hugo Azancot de Menezes, Américo Boavida e Eduardo Macedo dos Santos (MENEZES, 2018; ROCHA, 2003). A instalação do CVAAR no CongoLéopoldville é o que possibilita a entrada dos dirigentes do MPLA no país e o

\footnotetext{
${ }^{65}$ Ao citar o movimento africano "moderado" e "radical", Messiant se refere, respectivamente, ao "grupo de Monróvia", que reunia os países africanos moderados, e ao "grupo de Casablanca", do qual faziam parte Egito, Gana, Guiné Conacri, Mali, Marrocos e a FLN argelina. O MPLA se identificava com este último grupo.

${ }^{66}$ Para uma análise detalhada da primeira crise do MPLA, consultar Bittencourt (2002, capítulos III e IV, vol. 1; 2011); Mabeko-Tali (2018, p. 141-182) e Pinto (2016).

${ }^{67}$ Bittencourt (2002, p. 61-66, v. 1) nos chama a atenção para a ocorrência de revoltas anteriores, ambas inseridas num outro quadro de reivindicações e não coordenadas pelos principais movimentos de libertação de Angola: a manifestação ocorrida no Golungo Alto, em 11 de dezembro de 1960 e a Revolta de Cassanje, entre dezembro de 1960 e janeiro de 1961.
} 
início das atividades do movimento nesta cidade. Hugo Azancot de Menezes (2018, p. 132) assim descreve a chegada do Movimento: "Em novembro procedemos à inauguração de um dispensário de grandes dimensões e bem equipado [...] e iniciamos a publicação de um boletim mensal, Unidade Angolana, em português e em línguas nacionais”. O primeiro número deste boletim, datado de dezembro de 1961, ao qual tivemos acesso, relata, justamente, a inauguração do CVAAR em 7 de novembro de 1961. As páginas deste primeiro número do Unidade Angolana discutem, entre outros temas, a questão da luta armada e a necessidade da constituição de uma frente para a libertação de Angola. Também é publicado o relato de um sobrevivente do levante de fevereiro. A nota é assim intitulada: "Episódios da luta de libertação (1). A Revolta de Fevereiro. Diário de um sobrevivente".

Em sua análise da primeira grande crise no seio do MPLA, Mabeko-Tali (2018) indica que as suas causas foram de ordem racial, social e, de maneira determinante, ideológica.

Quanto à relação entre o MPLA e a UPA - que, em 1962, passa a integrar, junto ao Partido Democrático Angolano (PDA), a Frente Nacional de Libertação de Angola (FNLA) -, importa ressaltar que Holden Roberto acusava o MPLA de ser um movimento de comunistas, controlado por intelectuais mestiços e assimilados e que estaria distante das massas populares rurais, que constituíam a base de apoio interno à UPA/FNLA. Essas acusações atingem em cheio o núcleo dirigente do MPLA. Se o nascimento da UPA se deu "[...] num meio bakongo, urbanizado e exilado no antigo Congo Belga", a gênese do MPLA ocorre num meio crioulo $^{68}$ (oriundo, sobretudo, de Luanda), onde predominava uma pequena burguesia urbana assimilada: de um lado, mestiços provenientes de uma antiga classe média, bem como de camadas mais modestas; de outro, indivíduos negros, cujo estatuto de assimilado era mais recente e, portanto, mais frágil $\left(\right.$ MABEKO-TALI, 2018, p. 81) ${ }^{69}$.

\footnotetext{
68 O termo crioulo na África continental se refere, segundo Michel Cahen (2015, p. 39, nota 34), “...a um meio social africano específico produzido dentro e nas margens imediatas do aparelho colonial de Estado. Um crioulo pode ser branco, mestiço, negro, mas tem um estatuto sóciocultural particular".

69 Sobre as diferenças existentes no seio da sociedade colonial angolana e, em particular, sobre o fenômeno dos novos assimilados, ver Messiant, 2008a.
} 
É em função da necessidade do MPLA de se ligar às massas, sobretudo às massas camponesas, que Viriato da Cruz defende, em maio de 1962, em reuniões do Comitê Diretor, a retirada dos mestiços das posições de direção. A "retirada tática" dos mestiços configurava-se, pois, para Viriato em "[...] uma questão de sobrevivência para o MPLA em atenção à realidade circunvizinha, social e política, do país de acolhimento" (MABEKO-TALI, 2018, p. 153). Mas a aceitação da proposta de Viriato, que se deu após intenso debate ${ }^{70}$, significou uma derrota ao movimento quanto aos seus princípios: "A postura adotada por Viriato quanto ao lugar dos mestiços na direção", afirma Messiant (2003, p. 243), "opõe-se a vários dos seus camaradas do Comité Director - e, na prática, coloca-o numa posição que choca com o princípio de anti-racismo defendido pelo Movimento".

Ademais, o MPLA no Congo-Léopoldville se alarga demograficamente e sociologicamente, através incorporação de novos militantes, sendo a maioria deles refugiados do interior de Angola em virtude das insurreições de 1961. Este fato "[...] depressa quebrou a aparência de coesão que, até então, prevalecera no seio do primeiro núcleo das estruturas directivas do MPLA tomadas em Conakry" (MABEKO-TALI, 2018, p. 147-148).

No final de junho de 1962, Agostinho Neto conseguiu fugir de Portugal com o apoio do PCP ${ }^{71}$, dirigindo-se a Rabat, onde já era esperado pelas autoridades marroquinas e por Mário de Andrade na sede da CONCP (Conferência das Organizações Nacionalistas das Colónias Portuguesas) ${ }^{72}$. Neto, já investido do cargo de presidente do MPLA por Mário de Andrade, viajou a seguir ao CongoLéopoldville, onde se encontrava a direção do movimento. Essa data, que

\footnotetext{
70 Ver a transcrição da "Acta de reunião do Comité-Director" de 21 de maio de 1962 em MabekoTali (2018, p. 674-84).

71 Sobre a organização da fuga de Agostinho Neto pelo PCP, consultar: Carta de Lúcio Lara a Álvaro Cunhal, de 7 de maio de 1962, escrita a pedido de Viriato da Cruz (LARA, 2006, p. 235-236); Carta de Álvaro Cunhal a Lúcio Lara, de 7 de junho de 1962 (LARA, 2006, p. 409-410); Rocha (2003, p. 260-262).

72 De acordo com Rocha (2003, p. 181), em abril de 1961, 14 delegados, representantes de 11 movimentos nacionalistas (MPLA, PAIGC, Convenção de Goa, Udenamo e o representante de São Tomé e Príncipe, Miguel Trovoada), apoiados pelo governo Marroquino, reuniram-se em Casablanca. É desta reunião que nasceu a CONCP, cujo presidente foi Mário de Andrade, e cujos principais objetivos políticos eram: "Unidade de acção de todas as organizações nacionalistas com vista à liquidação completa e imediata do colonialismo português; Frente Unida à escala nacional; Cooperação entre as organizações nacionalistas das colónias portuguesas com vista ao desenvolvimento dos seus métodos de trabalho e dos seus meios de acção; Solidariedade com os povos de todos os países em luta contra o colonialismo e o imperialismo".
} 
culminará na primeira crise interna do MPLA, é representada pela oposição entre Viriato da Cruz e Agostinho Neto.

Segundo Mabeko-Tali (2018, p. 152-169), quando da sua chegada, Neto depressa se opôs à teoria de Viriato de "retirada tática" dos não negros dos órgãos de direção do MPLA, já que esta teoria se the constituía em um perigoso precedente (casado com uma branca e com filhos mestiços, Neto temia que essa decisão prejudicasse, a longo prazo, a sua família). Logo, esta decisão foi anulada na Conferência Nacional do MPLA, em dezembro de 1962.

Já a questão da trajetória social dos membros do MPLA trouxe à tona contradições que giravam em torno daqueles que possuíam ensino superior (obtido fora de Angola, geralmente na metrópole), os chamados "doutores", e daqueles que não o possuíam. Se considerarmos o contexto de fragilidade social e organizacional no qual o MPLA estava inserido, veremos que Agostinho Neto apresentava uma maior legitimidade em relação à Viriato da Cruz: 1. Neto era negro e, oriundo da região de ícolo e Bengo, pertencia ao grupo etnolinguístico kimbundu, que já constituía maioria nas estruturas intermediárias do movimento. 2. Neto possuía um título universitário, pois havia se formado em medicina em Coimbra. 3. Ao chegar em Léopoldville, Neto se encontrou com grande parte dos seus amigos e companheiros que, como ele, estudaram em Portugal e militaram no PCP ou em movimentos próximos a este partido, um círculo do qual viriato da Cruz se encontrava excluído. Ademais, o alinhamento total de Viriato, desde o início, com a política internacional de Pequim no contexto do cisma sinosoviético contribuiu para selar a sua exclusão desse círculo de relações, no qual Neto possuía protagonismo.

Logo, a questão ideológica teve um peso importante no desfecho desta crise. Em um artigo bastante esclarecedor sobre esta questão, o historiador Marcelo Bittencourt (2011) evoca a ideia de "cultura política", a fim de abordar a dinâmica das alianças externas como um fator de peso no desenrolar da crise. Se a trajetória de Viriato da Cruz estava mais voltada para a China, a de Agostinho Neto apontava para um rumo diferente, marcado por sua ligação ao PCP e a outros líderes africanos. Em dezembro de 1962, foi organizada uma Conferência Nacional da qual o último sai vitorioso. De acordo com Mário de Andrade, 
Quando se pôs a questão da direção, houve duas listas: uma que incluía o nome de Viriato da Cruz, e outra que não o incluía. Houve uma escolha da Conferência a favor de uma lista de direção que era uma ruptura definitiva - uma ruptura que Neto tinha exigido. Neto exigia que a direção excluísse Viriato da Cruz. (ANDRADE, 1997, p. 180)

Após a sua expulsão do MPLA, bem como de vários dos seus companheiros, Viriato ingressou, com a sua facção, na FNLA, em julho de 1963. Formou-se o grupo MPLA-Viriato, uma dissidência, cuja permanência no seio desta Frente foi efêmera e que, de acordo com Serrano (2012, p. 167), não conseguiu "[...] catalisar a força necessária para conduzir a luta ou transformá-la em uma etapa superior do processo revolucionário". Mais do que isso, tal decisão de Viriato provocou um descontentamento em muitos daqueles que compartilhavam das suas ideias e o apoiavam no interior do MPLA desde o início (MABEKO-TALI, 2018, p. 174).

\section{O exílio chinês de Viriato da Cruz}

Ao ser expulso do MPLA, Viriato passa a acusar os seus antigos companheiros de se aproximarem da corrente "revisionista", reforçando, com esta acusação, a sua oposição ao comunismo soviético e "agarrando-se à opção chinesa - de facto a única possível na configuração mundial, africana e angolana - enquanto revolucionário, radical e anti-soviético" (MESSIANT, 2003, p. 258). De acordo com Serrano (2012, p. 1967), os conflitos no seio do MPLA colocaram Viriato e seus apoiadores em uma situação de constante perigo físico (após o assassinato de Matias Miguéis e José Miguel ${ }^{73}$ ) e conduziram Viriato e a sua esposa a um exílio na Argélia (1963-1965).

Depois da sua passagem pela Argélia, Viriato segue sozinho, em dezembro de 1965, para Paris ${ }^{74}$, onde se hospeda nas casas de Mário Clington e de Rui Castro Lopo (LABAN; MESSIANT, 2003, p. 24, nota 2). Pouco se sabe sobre esta estadia de Viriato da Cruz em Paris. Segundo Messiant, Viriato, que já integrara o grupo da importante revista Présence Africaine, em função desse vínculo, teria

\footnotetext{
73 Ver nota 18 , supra.

${ }^{74}$ De acordo com uma carta de Viriato da Cruz a José Carlos Horta, datada de 20/12/1965.
} 
trabalhado temporariamente no CNRS (Centre National de la Recherche Scientifique).

A partir de 1966, Viriato, acompanhado da sua esposa, Maria Eugénia, e da sua filha de 3 anos, Marília, muda-se para a China em virtude de um convite para assumir um cargo de liderança da ala pró-chinesa do Bureau da OEAA, cuja sede se instalara em Pequim, após a cisão com a ala soviética ${ }^{75}$. Viriato teria recusado este cargo de liderança, mas aceitara ser o consultor para a África e as colônias portuguesas. Ao chegar em Pequim, foi hospedado com a sua família no Hotel da Amizade (Youyi binguan), destinado aos estrangeiros.

No dia nacional da República Popular da China, comemorado no 10 de outubro de 1966, Viriato proferiu um discurso na tribuna da Praça Tien Na-men, na presença do presidente Mao Tsé-Tung, do vice-presidente Liu Shaoqi e do primeiro-ministro Chu En-Lai. Nesse discurso, denunciou o imperialismo americano e atacou o revisionismo soviético, defendendo uma "frente única internacional" contra o imperialismo americano que deveria congregar os povos da Ásia, da África e da América Latina (CHAJMOWIEZ, 2003; DÁSKALOS, 2000; FERNANDES, 2008; MESSIANT, 2003).

Entre 15 de novembro de 1966 e a primeira semana de janeiro de 1967, Viriato da Cruz integrou a "delegação da amizade" da OEAA na realização de uma viagem a vários países da África e da Ásia. Ao apresentar um relatório sobre a possibilidade da expansão do socialismo em África, Viriato, de acordo com o relato de Monique Chajmowiez ${ }^{76}$, manifestou-se negativamente à viabilidade dessa expansão, contrariando a orientação oficial do regime chinês.

No entanto, de acordo com Su (2020, p. 856), e segundo um ex-colega chinês de Viriato da Cruz, o gatilho para a sua desgraça política foi uma foto tirada com o então presidente chinês, Liu Shaoqi, durante a "Emergency Metting"

\footnotetext{
${ }^{75}$ A respeito da participação de Viriato da Cruz na "Emergency Meeting" ("Reunião Emergencial"), que culminou na ruptura entre a ala chinesa e a ala soviética da OEAA, consultar Sun (2020, p. 853-854).

${ }^{76}$ Militante maoísta francesa que conheceu Viriato da Cruz durante a sua estadia em Pequim entre 1968 e 1970, quando trabalhou no departamento francês do semanário PequimInformação. Os originais das cartas intercambiadas entre ambos, bem como alguns escritos de Viriato que se encontravam em posse de Monique Chajmowiez, encontram-se na Fundação Mário Soares (FMS), em Lisboa; as digitalizações desse espólio podem ser encontradas no portal Casa Comum: casacomum.org/cc/arquivos.
} 
(“Reunião Emergencial”), ocorrida entre 27 de junho e 9 de julho de 1966. Durante os anos da Revolução Cultural - 1966 a 1976 -, sobretudo nos seus primeiros anos, Liu Shaoqi foi duramente atacado e acusado de ser o líder da via capitalista de desenvolvimento. Aqueles que eram considerados seus seguidores por determinada(s) facção(ões) de extrema-esquerda da Guarda Vermelha foram perseguidos, interrogados ou mesmo torturados ou presos (incluindo alguns especialistas estrangeiros que trabalhavam e viviam na China durante esse período ${ }^{77}$ ). Viriato da Cruz teria se recusado a remover a sua foto com Liu do seu quarto, no apartamento onde residia com a sua família, ou a chamar o expresidente de líder da "via capitalista", apesar de ter sido aconselhado pelos mais "radicais" a isto.

Em 1969, Viriato perdeu o seu emprego na OEEA e iniciou uma série de diligências para sair da China com a sua família, contudo, sem êxito (FERNANDES, 2008; LABAN; MESSIANT, 2003). O deterioro da sua saúde e o agravamento das suas condições materiais aumentavam a cada dia. Em uma carta ao seu amigo Horta de 23 de abril de 1970, Viriato assim se refere à sua situação material:

Quanto a mim, neste momento - e neste país cuja língua não falo, e onde não tenho relações com nenhum indígena - estou sem recursos materiais e sem os meios de os obter, pois, como te disse, estou desempregado há mais de um ano. Há quase um mês que vivo de empréstimos junto de alguns estrangeiros. (CRUZ, 1970a, p. 2)

Em maio de 1970, mais um incidente contribuiu para o agravamento do deterioro emocional e físico de Viriato da Cruz. Em carta de 31 de outubro de 1970 a José Carlos Horta, Viriato the contou que fora intimado a se apresentar à polícia chinesa. Temendo ser isto uma "provocação" ou uma "ratoeira", Viriato, antes de apresentar, queima "[...] não somente aquele trabalho [escrito em Paris no inverno de 1965], mas ainda 13 (treze) manuscritos (cerca de quatrocentas páginas) tratando de questões políticas, sociais, históricas, etc. de Angola, de África, de Portugal, etc." (VIRIATO, 1970b, p. 3). E prossegue o seu doloroso relato: “Esses manuscritos tinha-o eu composto a partir de estudos e pesquisas que fiz

\footnotetext{
77 Ver, a esse respeito, Beverley Hooper, Foreigners under Mao. Western lives in China, 1949-1976. Hong Kong: Hong Kong University Press, 2016.
} 
principalmente nestes últimos oito anos. Trabalho inútil! Esforços baldados! Tempo perdido! Quando penso nisso, sinto... não sei o quê" (VIRIATO, 1970b, p. 3).

E, em uma carta datada de 30 de abril de 1971, Viriato enfim revela ao amigo Horta a complexa situação que envolve o seu delicado estado de saúde:

Atenta, pois, no seguinte: em 1967, eu estive hospitalizado, aqui, durante mês e meio. A partir desse momento, meus médicos teriam talvez tido o dever (de acordo, ao que me parece, com a moral profissional médica) de me submeter a um tratamento sistemático. Entretanto, apesar de eu ter ido muitas vezes a consultas médicas nestes últimos quatro anos, só foi a partir de há dez ou onze meses que os médicos decidiram submeter-me a um tratamento sistemático. (CRUZ, 1971a, p. 1)

Viriato da Cruz e sua família chegaram em Pequim em plena Revolução Cultural e acabaram por se tornarem reféns de muitas das contradições que assolaram esse período da história chinesa. A sua situação se agravou ainda mais quando foram removidos do Hotel da Amizade e deslocados a P'ou Houang-U, um bairro situado ao sul de Pequim. Em uma carta a Horta, datada de 13 de outubro de 1971, Viriato the comunica o seu novo endereço, no entanto, sem oferecer qualquer detalhe sobre o que se teria passado (CRUZ, 1971b) ${ }^{78}$. O bairro para o qual Viriato e família foram removidos não the oferecia condições mínimas de trabalho e lá permaneceram isolados do convívio com os outros estrangeiros (CHAJMOWIEZ, 2003, p. 62). Em 13 de junho de 1973, após mais de dois meses de internação no Hospital Nacional, em Pequim, Viriato da Cruz falece em um contexto de isolamento e anonimato.

\footnotetext{
${ }^{78}$ Segundo José Carlos Horta, a correspondência que Viriato the enviava apresentava sinais de ter sido violada (Comunicação Pessoal, mai. 2019). Também Viriato expressava em algumas de suas cartas que tudo o que escrevia era lido pelas autoridades chinesas.
} 


\section{Referências}

ANDRADE, Mário Pinto de. [Carta de Mário de Andrade]. Destinatário: Lúcio Lara. Monschau, 7 mar. 1960. 1 carta. In: LARA, Lúcio. Um amplo movimento...: itinerário do MPLA através de documentos e anotações (até fevereiro de 1961). 3ed. rev. e aum. Luanda: Edição do autor, 2017a. p. 313-314. v. 1.

ANDRADE, Mário Pinto de. [Carta de Mário de Andrade]. Destinatário: Lúcio Lara. Düren, 16 mar. 1960. 1 carta. In: LARA, Lúcio. Um amplo movimento... Itinerário do MPLA através de documentos e anotações (até fevereiro de 1961). 3ed. rev. e aum. Luanda: Edição do autor, 2017b. p. 335-337. v. 1.

ANDRADE, Mário Pinto de. Sur la Première génération du MPLA: 1948-1960. Mário de Andrade, entretiens avec Christine Messiant (1982). Lusotopie : dynamiques religieuses en lusophonie contemporaine. Paris: Éditions Karthala, 1999. p. 185221.

ANDRADE, Mário Pinto de. Uma entrevista dada a Michel Laban. Lisboa: Edições João Sá da Costa, 1997.

BITTENCOURT, Marcelo. “Estamos Juntos!": o MPLA e a luta anticolonial (19611974). 2002. Tese (Doutorado em História) - Universidade Federal Fluminense, Niterói. 2002. 2 v.

BITTENCOURT, Marcelo. A criação do MPLA. Estudos Afro-Asiáticos, Rio de Janeiro, p. 185-208, n. 32, dez. 1997.

BITTENCOURT, Marcelo. Dos jornais às armas. Lisboa: Vega, 1999.

BITTENCOURT, Marcelo. Fissuras na luta de libertação angolana. Métis. História \& Cultura, Caxias do Sul, p. 237-255, v.10, n. 19, jan./jun. 2011.

BOURDIEU, Pierre. L'ilusion biographique. Actes de la Recherche en Sciences Sociales, Paris, p. 69-72, n. 62-63, 1986.

BRANCO, Zillah. O poder jurídico e a responsabilidade ética e histórica. In: MEDINA, Maria do Carmo. Angola: processos políticos da luta pela independência. 3. ed. Coimbra: Almedina, 2013. p. 11-14.

CAHEN, Michel. Pontos comuns e heterogeneidade das culturas políticas nos PALOPS. Um ponto de vista "pós-póscolonial". História: Questões \& Debates, Curitiba, p. 19-47, v. 62, n. 1, jan./jun. 2015.

CAHEN, Michel. Posface. Militante de la Connaissance. In: CAHEN, Michel ; LACHARTRE, Brigitte (orgs.). L'Angola post-colonial: sociologie politique d'une oléocratie. Paris: Khartala, 2008. p. 395-415. v. 2.

CAHEN, Michel; FORTUNA, Cláudio. Entrevista a Michel Cahen. "Quer a Frelimo e o MPLA, quer a Renamo e a Unita, são partidos profundamente diferentes": 
pesquisando os passos de Christine Messiant. Revista Angolana de Sociologia, Luanda, n. 12, p. 127-153, 2013.

CHAJMOWIEZ, Monique. Entrevista a Monique Chajmowiez, por Christine Messiant e Michel Laban. In: LABAN, Michel (org.). Viriato da Cruz: cartas de Pequim. Luanda: Edições Chá de Caxinde, 2003. p. 37-63.

CRUZ, Viriato da. [Introdução]. In: LEVAUX, Marcel et al (ed.). La Répression Colonialiste en Angola: le procès des cinquante. 2. ed. Cheratte: [s.n.], 3 ago. 1960. p. 2-4.

CRUZ, Viriato da. [Carta de Viriato da Cruz]. Destinatário: José Carlos Horta. Pequim, 14 out. 1970. 1 carta. In: LABAN, Michel (org.). Viriato da Cruz: cartas de Pequim. Luanda: Edições Chá de Caxinde, 2003a. p. 115-137.

CRUZ, Viriato da. [Carta de Viriato da Cruz]. Destinatário: José Carlos Horta. Pequim, 31 out. 1970b. 1 carta pessoal.

CRUZ, Viriato da. [Carta de Viriato da Cruz]. Destinatário: Lúcio Lara. [S.l], 29 out. 1959. 1 carta. In: LARA, Lúcio. Um amplo movimento...: itinerário do MPLA através de documentos e anotações (até fevereiro de 1961). 3. ed. rev. e aum. Luanda: Edição do autor, 2017a. p. 154-163. v. 1.

CRUZ, Viriato da. [Carta de Viriato da Cruz]. Destinatário: Lúcio Lara. [S.l.], 22 nov. 1959. 1 carta. In: LARA, Lúcio. Um amplo movimento...: itinerário do MPLA através de documentos e anotações (até fevereiro de 1961). 3. ed. rev. e aum. Luanda: Edição do autor, 2017b. p. 175-179. v. 1.

CRUZ, Viriato da. [Carta de Viriato da Cruz]. Destinatário: Lúcio Lara. [S.l.], 6 dez. 1959. 1 carta. In: LARA, Lúcio. Um amplo movimento...: itinerário do MPLA através de documentos e anotações (até fevereiro de 1961). 3. ed. rev. e aum. Luanda: Edição do autor, 2017c. p. 211-215. v. 1.

CRUZ, Viriato da. [Carta de Viriato da Cruz]. Destinatário: Lúcio Lara. Conacri, 1 jul. 1960. 1 carta. In: LARA, Lúcio. Um amplo movimento...: itinerário do MPLA através de documentos e anotações (até fevereiro de 1961). 3. ed. rev. e aum. Luanda: Edição do autor, 2017h. p. 398-399. v. 1.

CRUZ, Viriato da. [Carta de Viriato da Cruz]. Destinatário: Lúcio Lara. Conacri, 11 jul. 1960. 1 carta. In: LARA, Lúcio. Um amplo movimento...: itinerário do MPLA através de documentos e anotações (até fevereiro de 1961). 3. ed. rev. e aum. Luanda: Edição do autor, 2017i. p. 403-404. v. 1.

CRUZ, Viriato da. [Carta de Viriato da Cruz]. Destinatário: Salim Miguel. [S.l.], 23 set. 1952. 1 carta. In: MIGUEL, Salim. Cartas d’África e alguma poesia. Rio de Janeiro: Topbooks; Academia Brasileira de Letras, 2005. p. 38-39. 
CRUZ, Viriato da. [Carta de Viriato da Cruz]. Destinatários: Lúcio Lara; Amílcar Cabral. Conacri, 14 mar. 1960. 1 carta. In: LARA, Lúcio. Um amplo movimento...: itinerário do MPLA através de documentos e anotações (até fevereiro de 1961). 3. ed. rev. e aum. Luanda: Edição do autor, 2017e. p. 332-333. v. 1.

CRUZ, Viriato da. [Carta de Viriato da Cruz]. Destinatários: Lúcio Lara [e amigos]. Conacri, 17 mar. 1960. 1 carta. In: LARA, Lúcio. Um amplo movimento...: itinerário do MPLA através de documentos e anotações (até fevereiro de 1961). 3. ed. rev. e aum. Luanda: Edição do autor, 2017f. p. 337-341. v. 1.

CRUZ, Viriato da. [Carta de Viriato da Cruz]. Destinatários: Lúcio Lara; Amílcar Cabral. Concri, 18 mar. 1960. 1 carta. In: LARA, Lúcio. Um amplo movimento...: itinerário do MPLA através de documentos e anotações, v. I, até fevereiro de 1961. 3. ed. rev. e aum. Luanda: Edição do autor, 2017g. p. 346-349.

CRUZ, Viriato da. [Correspondência]. Destinatário: Abel Francisco da Cruz. Luanda, 4 nov. 1946. 1 carta pessoal.

CRUZ, Viriato da. [Correspondência]. Destinatário: José Carlos Horta. Pequim, 23 abr. 1970a. 1 carta pessoal.

CRUZ, Viriato da. [Correspondência]. Destinatário: José Carlos Horta. Pequim, 30 abr. 1971a. 1 carta pessoal.

CRUZ, Viriato da. [Correspondência]. Destinatário: José Carlos Horta. Pequim, 13 out. 1971b. 1 carta pessoal.

CRUZ, Viriato da. Angola: quelle indépendance... Révolution. Revue mensuelle internationale, Paris, p. 5-16, n. 6, fev. 1964.

CRUZ, Viriato da. Cartas de Viriato da Cruz a Monique Chajmowiez. In: LABAN, Michel (org.). Viriato da Cruz: cartas de Pequim. Luanda: Edições Chá de Caxinde, 2003b. p. 65-212.

CRUZ, Viriato da. Des responsabilités d'intellectuel noire. Comunicação de Viriato da Cruz ao 2o Congresso dos Escritores e Artistas Negros (Roma, 26 de março a 10 de Abril, 1959). Présence Africaine, Paris, p. 321-339, n. 27-28, ago./nov. 1959.

CRUZ, Viriato da. Documento sem data manuscrito por Viriato da Cruz conhecido como "Manifesto do MPLA". Luanda: Associação Tchiweka de Documentação (ATD): Fundo: Arquivo Lúcio Lara. 1956a. 17 p. Disponível em: https://www.tchiweka.org/documento-textual/0003000013. Acesso em: 20 out. 2021. 
CRUZ, Viriato da. Intervenção de Viriato da Cruz na 2a Conferência de Solidariedade dos Povos Afro-Asiáticos. Conacri, 11-15 de abr. 1960. In: LARA, Lúcio. Um amplo movimento...: itinerário do MPLA através de documentos e anotações (até fevereiro de 1961). 3. ed. rev. e aum. Luanda: Edição do autor, 2017d. p. 367-369. v. 1.

CRUZ, Viriato da. Manifesto do MPLA (Cópia a papel químico...). Lisboa: Fundação Mário Soares: Arquivo Mário Pinto de Andrade. dez. 1956b. 48 p. Disponível em: http://casacomum.org/cc/visualizador?pasta=04357.005.001\#!1. Acesso em: 27 nov. 2017.

CRUZ, Viriato da. Manifesto do MPLA (Movimento Popular de Libertação de Angola). Lisboa: Fundação Mário Soares: Arquivo Mário Pinto de Andrade, dez. 1956. Disponível em:

http://casacomum.org/cc/visualizador?pasta=04334.004.002\#!1. Acesso em: 27 nov. 2017.

CRUZ, Viriato da. Primeira impressão sobre a China. Lisboa: Fundação Mário Soares: DAC - Documentos Amílcar Cabral, 1960. Manuscrito. Disponível em: http://hdl.handle.net/11002/fms_dc_42635. Acesso em: 27 nov. 2017.

DÁSKALOS, Sócrates. Um testemunho para a história de Angola. De Huambo a Huambo. Lisboa: Editora Vega, 2000.

FERNANDES, Moisés Silva. O percurso chinês de Viriato da Cruz, 1958-1973. In: ROCHA, Edmundo; SOARES; Francisco; FERNANDES, Moisés Silva. Viriato da Cruz: o homem e o mito. Porto Amboim (Angola) 1928 - Beijing (China) 1973. Lisboa: Editora Prefácio; Luanda: Chá de Caxinde, 2008. p. 255-342.

HISTÓRIA DO MPLA. 1o Volume (1940-1966). Luanda: Edição CDIH (Centro de Documentação e Investigação Histórica do Comité Central do MPLA), 2014.

HORTA, José Carlos. Actividades políticas entre 1951 e 1974. Algés: [s.n], fev. 2010.

INFORME político. In: Congresso do Partido Comunista Português, 5., 1957, [Lisboa]. [Anais]. Lisboa: Edições Avante, out. 1957. Fundação Mário Soares: Fundo DST - Documentos Souto Teixeira. Disponível em:

http://casacomum.org/cc/visualizador?pasta=04435.791\#!1. Acesso em: 20 maio 2020.

JACINTO, António. [Carta de António Jacinto]. Destinatário: Mário Pinto de Andrade. Luanda, 1 fev. 1952. 1 carta. In: ANDRADE, Mário Pinto de. Uma entrevista dada a Michel Laban. Lisboa: Edições João Sá da Costa, 1997. p. 189195. 
JACINTO, António. [Carta de António Jacinto]. Destinatário: Salim Miguel. [S.l.], 9 out. 1955. 1 carta. In: MIGUEL, Salim. Cartas d'África e alguma poesia. Rio de Janeiro: Topbooks; Academia Brasileira de Letras, 2005. p. 26-27.

JACKSON, Steven F. China's third world foreign policy: the case of Angola and Mozambique, 1961-93. The Chine Quarterly, Cambridge, v. 142, p. 388-422, Jun. 1994.

LABAN, Michel; MESSIANT, Christine. Vamos descobrir Viriato: cartas de Pequim. In: LABAN, Michel (org.). Viriato da Cruz: cartas de Pequim. Luanda: Edições Chá de Caxinde, 2003. p. 23-34.

LARA, Lúcio. Um amplo movimento...: itinerário do MPLA através de documentos e anotações (até fevereiro de 1961). 3. ed. rev. e aum. Luanda: Edição do autor, 2017. v. 1.

LARA, Lúcio. Um amplo movimento...: itinerário do MPLA através de documentos e anotações (1961-1962). Luanda: Edição do autor, 2006. v. 2.

LARA, Lúcio. Um amplo movimento...: itinerário do MPLA através de documentos e anotações (1963-1964). Luanda: Edição do autor, 2008. v. 3.

LEVAUX, Marcel et al. (ed.). La repression colonialiste en Angola: le proces des cinquante. 2. ed. Cheratte: [s.n.], 3 ago. 1960.

MABEKO-TALI, Jean-Michel. Guerrilhas e lutas sociais: o MPLA perante a si próprio. 1960-1977. Lisboa: Mercado das Letras, 2018.

MACAGNO, Lorenzo. A invenção do assimilado: paradoxos do colonialismo em Moçambique. Lisboa: Edições Colibri, 2019.

MARCUM, John. The Angolan revolution: exile politics and guerrilla warfare, 1926-1976. Cambridge, MA: MIT Press, 1978.

MARCUM, John. The Angolan revolution: the anatomy of an explosion, 19501962. Cambridge, MA: MIT Press, 1969.

MATEUS, Dalila Cabrita. A PIDE/DGS na Guerra Colonial, 1961-1974. Lisboa: Terramar, 2004.

MEDINA, Maria do Carmo. Angola: processos políticos da luta pela independência. 3. ed. Coimbra: Almedina, 2013.

MENEZES, Hugo Azancot de. Percursos da luta de libertação nacional. Viagem ao interior do MPLA. Memórias Pessoais. 2ed. Lisboa: Nova Vega e Herdeiros do Autor, 2018. 
MESSIANT, Christine. Chez nous, même le passé est imprévisible. L'experience d'une recherche sur le nationalisme angolais, et particulièrement le MPLA: sources, critiques, besoins actuels de la recherche. In: L'Angola postcolonial: sociologie politique d'une oléocratie. Paris: Khartala, 2008b. p. 153-202. v. 2.

MESSIANT, Christine. Luanda (1945-1961): colonisés, société coloniale et engagement nationalista. In: L'Angola postcolonial: sociologie politique d'une oléocratie. Paris: Karthala, 2008a. p. 17-103. v. 2.

MESSIANT, Christine. Viriato da Cruz em Pequim: as provações de um revolucionário angolano. Esboço de um percurso e tentativa de interpretação. In: LABAN, Michel (org.). Viriato da Cruz: cartas de Pequim. Luanda: Edições Chá de Caxinde, 2003. p. 215-360.

MIGUEL, Salim. Cartas d’África e alguma poesia. Rio de Janeiro: Topbooks; Academia Brasileira de Letras, 2005.

MPLA. Crise de Novembro 1962. Acta da Reunião realizada na sede do MPLA, em Léopoldville, no dia 12 de outubro de 1962. Lisboa: Fundação Mário Soares: Arquivo Mário Pinto de Andrade. Disponível em:

http://casacomum.org/cc/visualizador?pasta=04356.001.013\#!1. Acesso em: 10 out. 2020.

NUNES, António. O regime salazarista nos anos sessenta visto pelo jornal Le Monde. Revista de História das Ideias, Coimbra, p. 481-511, v. 17, 1995.

O MANIFESTO - original ou cópia? Esclarecimento (final) da Associação Tchiweka de Documentação, Jornal de Angola, Luanda, p. 4, 17 ag. 2019b. Disponível em: https://www.facebook.com/803802836492514/photos/a.803872759818855/11256 18847644243/. Acesso: 3 set. 2019.

O MANIFESTO - original ou cópia? Esclarecimento da Associação Tchiweka de Documentação, Jornal de Angola, Luanda, p. 6-7, 4 ag. 2019a. Disponível em: https://www.facebook.com/803802836492514/posts/1113089148897213/. Acesso: 3 set. 2019.

OLIVEIRA, Mário António. Reler África. Coimbra: Universidade de Coimbra, Instituto de Antropologia, Centro de Estudos Africanos, 1990.

PACHECO, Carlos. MPLA: um nascimento polémico (as falsificações da história). Lisboa: Vega, 1997.

PATO, Helena. Maria do Carmo Medina. Jornal Tornado, Entroncamento, 9 abr. 2017. Disponível em: https://www.jornaltornado.pt/maria-do-carmo-medina/. Acesso em: 10 abr. 2020. 
PÉLISSIER, Réne. La colonie du Minotaure: nationalismes et révoltes en Angola (1926-1951). Orgeval: Éditions Pélissier; Montamets, 1978.

PESTANA, Nelson. [Correspondência]. Destinatário: Angela Lazagna. Lisboa, 10 jul. 2021. 1 e-mail pessoal.

PESTANA, Nelson. O manifesto de Viriato da Cruz (1956). Luanda, 2017. Disponível em: http://www.ceic-ucan.org/wp-content/uploads/2017/02/OMANIFESTO-DEVIRIATO-DA-CRUZ.pdf. Acesso: 21 jan. 2018.

PESTANA, Nelson. O Partido Comunista de Angola de Viriato da Cruz. Lucere. Revista Académica da UCAN, Luanda, p. 127-156, dez. 2016.

PINTO, João Paulo Henrique. A questão identitária na crise do MPLA (1962-1964). Revista TEL, Irati, v. 7. n. 2, p. 140-169, jul./dez. 2016.

RAMOS, Karina. A angolanidade literária nas páginas da revista Mensagem (19511952). Transversos: Revista de História, Rio de Janeiro, p. 278-296, n. 10, ag. 2017.

RESOLUTION de la Conférence d'Accra sur le colonialisme et l'impérialisme. La Gauche, Organe de Combat Socialiste, [s.l.], 10 jan. 1959.

ROCHA, Edmundo. Angola: contribuição ao estudo da génese do nacionalismo moderno angolano (período de 1950-1964) (testemunho e estudo documental). Lisboa: Kilombelombe, 2003.

ROCHA, Edmundo. O itinerário político de Viriato da Cruz (até a crise no MPLA de 1963-1964). In: ROCHA, Edmundo; SOARES; Francisco; FERNANDES, Moisés Silva. Viriato da Cruz: o homem e o mito. Porto Amboim (Angola) 1928 - Beijing (China) 1973. Lisboa: Editora Prefácio; Luanda: Chá de Caxinde, 2008. p. 109-184.

SANTIAGO, Onélio. Um prémio com sabor de redenção. Jornal Nova Gazeta, Luanda, 8 nov. 2018. Disponível em: https://www.novagazeta.co.ao/artigo/701. Acesso em: 01 jun. 2019.

SANTIL, Juliana Marçano. [Carta de Juliana Santil]. Destinatários: Eglê Malheiros; Salim Miguel. [S.l], 18 maio 2005. 1 e-mail. In: MIGUEL, Salim. Cartas d'África e alguma poesia. Rio de Janeiro: Topbooks; Academia Brasileira de Letras, 2005. p. 141-143.

SANTIL, Juliana Marçano. "Ce metis qui nous trouble": Les représentations du Brésil dans l'imaginaire politique angolais: l'empreinte de la colonialité sur le savoir. 2006. Thèse (Doctorat en Sciences Politiques) - École Doctorale de Science Politique de Bordeaux; Université Montesquieu - Bordeaux IV; Institut d'Études Politiques de Bordeaux; Centre d'Études d'Afrique Noire), Bordeaux, 2006. 
SANTOS, Daniel dos. Amílcar Cabral: um outro olhar. Lisboa: Editora Chiado, 2014.

SERRANO, Carlos. Angola, nascimento de uma nação: um estudo sobre a construção da identidade nacional. Luanda: Edições Kilombelembe, 2009a.

SERRANO, Carlos. Carlos Serrano: um intelectual entre a memória e a nação. Entrevista realizada por Osvaldo Silva. Revista Crioula, São Paulo, n. 6, nov. 2009b. Disponível em: https://www.revistas.usp.br/crioula/issue/view/4425. Acesso em: 27 nov. 2017.

SERRANO, Carlos. Viriato da Cruz: um intelectual angolano do século XX. A memória que se faz necessária. África: Revista do Centro de Estudos Africanos. São Paulo: USP, p. 165-178, 2012. Número especial.

SILVEIRA, Anabela. O "Comunismo" de Viriato da Cruz e os seus reflexos no nacionalismo angolano. In: CONGRESSO DA HISTÓRIA CONTEMPORÂNEA, 2., Évora, maio 2013. Comunicação [...]. [S.l.]: Academia, 2013. Disponível em: https://www.academia.edu/10513124/O_comunismo_de_Viriato_da_Cruz_e_os_s eus_reflexos_no_nacionalismo_angolano. Acesso em: 19 jan. 2018.

SOARES, Francisco. No cruzar dos caminhos: pesquisa poética de Viriato da Cruz. In: ROCHA, Edmundo; SOARES; Francisco; FERNANDES, Moisés Silva. Viriato da Cruz: o homem e o mito. Porto Amboim (Angola) 1928 - Beijing (China) 1973. Lisboa: Editora Prefácio; Luanda: Chá de Caxinde, 2008. p. 71-106.

SUN, Jodie Yuzhou. Viriato da Cruz and his chinese exile: a biographical approach, Journal of Southern African Studies, London, v. 46, n. 5, 2020, p. 845861. 